\title{
Firm Level Evidence of Disaster Impacts on Growth in Vietnam
}

\author{
Fujin Zhou ${ }^{1}$ (D) Wouter Botzen ${ }^{1,2,3}$
}

Accepted: 13 April 2021 / Published online: 30 April 2021

(c) The Author(s) 2021

\begin{abstract}
The theory about the impacts of natural disasters on firms is ambiguous and the empirical evidence on this topic is scarce, which hampers the design of disaster risk reduction and climate change adaptation policies. In this paper we identify the short-run impacts of storms and floods on firm growth in labor, capital, and sales, using Enterprise Census data (2000-2014) for Vietnam. We define storms and floods with three different disaster measures: physical intensities, number of deaths, and economic damage. The performance of these disaster measures is compared by estimating dynamic growth models using the Blundell-Bond system generalized method of moments. We find evidence that flooding increases labor growth and capital growth but reduces sales growth significantly up to 3 years after flooding. We also find some evidence of positive impacts on labor growth and capital growth but mostly negative impacts on sales growth for storms within 3 years after storms strike. The impacts of floods and storms on firm growth are more pronounced and persistent for small and medium sized firms. Finally, unlike at the macro level, the direction and scale of disaster impacts found at the firm level are fairly consistent across the three disaster measures.
\end{abstract}

Keywords Natural disaster · Disaster impact · Firm growth $\cdot$ Physical intensity $\cdot$ GMM

\section{Introduction}

Natural disasters such as storms, floods, and droughts, are becoming more frequent and severe worldwide, resulting in large socioeconomic consequences (IPCC 2014). Many scientists tend to attribute the trend of rising natural disaster losses to increases in wealth and

Fujin Zhou

fujin.zhou@vu.nl

Wouter Botzen

wouter.botzen@vu.nl

1 Department of Environmental Economics, Institute for Environmental Studies (IVM), Vrije Universiteit, $1081 \mathrm{HV}$ Amsterdam, The Netherlands

2 Utrectht University School of Economics (USE), Utrecht University, Utrecht, The Netherlands

3 Risk Management and Decision Processes Center, The Wharton School, University of Pennsylvania, Philadelphia, USA 
population levels in disaster-prone regions, and possibly climate change (Bouwer 2019; Estrada et al. 2015). Both developed and developing countries are vulnerable to the economic impacts of climate change, but it is expected that these impacts will be more severe in developing countries which have a limited capacity to adapt to climate change (Tol 2018). Therefore, adapting to changes in climate and limiting the effects of changes in the intensity and/or frequency of natural hazards on economic development are important.

For climate change adaptation and enhancing the preparedness and resilience of a society, it is essential to understand the relationship between natural disasters and economic activities. Disaster impacts can be divided into direct impacts, like property losses, and indirect economic impacts, such as effects on economic growth (Cavallo and Noy 2011). The former impacts are relatively well understood, while insights into economic growth impacts of natural disasters are more uncertain (Lazzaroni and van Bergeijk 2014; Botzen et al. 2019). Hallegatte and Przyluski (2010) has emphasized the importance of estimating the indirect losses to assess the consequences of natural disasters on welfare. However, the evidence for disaster impacts on economic growth is inconclusive and is mostly obtained from highly aggregated macroeconomic data at the country or regional levels (Klomp and Valckx 2014; Lazzaroni and van Bergeijk 2014). This inconsistency in results is in part related to the failure to fully account for the differences in disaster types, locations, economic and financial development, institutional quality, time periods used for the analysis, disaster cost definitions, and assessment methodologies (Loayza et al. 2012; Cavallo et al. 2013; Felbermayr and Gröschl 2014).

This paper contributes to understanding the impact of disasters on economic growth by examining at the firm level the relationship between natural disasters and business activities in the short run. Understanding firm responses to natural disasters helps design efficient responses to natural disasters. The impacts of natural disasters on the macro-economy largely materialize through their effects on firms through the generation of jobs and income. Natural disasters are exogenous shocks that directly affect firms' production and demand for production inputs, and induce resource reallocation in the process of firm exit, entry, and the expansion and contraction of existing firms (Leiter et al. 2009; Tanaka 2015; Cole et al. 2015). Through their direct effects on firms, natural disasters have ripple effects on society at large, for example through the loss of jobs, reduction of income, and disruptions in the supply of goods and services (Tierney 2007). Indirect effects of disasters on firms may also be positive, for example when firms that are not directly hit take over production from firms with damaged production facilities, or when demand for products and services increases in the recovery phase after a disaster. Therefore, firms should play an important role in climate change adaptation and disaster risk reduction (Musso and Schiavo 2008). But there is limited evidence on how disasters impact firms so far (Leiter et al. 2009; Tanaka 2015; Cole et al. 2015).

In this paper, we investigate the impacts of storms and floods on firm growth in Vietnam, a developing country particularly vulnerable to climate change and natural hazards. ${ }^{1}$ With a coastline of $3440 \mathrm{~km}$ and an estimated $70 \%$ of the population living in coastal areas and low-lying deltas (GFDRR 2015), Vietnam is highly exposed to a wide range of natural hazards such as floods, storms (or typhoons), landslides, and droughts. Floods and tropical storms are the most frequent and destructive natural hazard events in Vietnam with

\footnotetext{
1 Vietnam is ranked as one of the most vulnerable countries (6th) to climate change according to land area impacted, population affected, economic loss, and the coping and adaptive capacity of the country to natural hazards (World Bank 2010).
} 
the highest number of fatalities and economic damages between 1990 and 2014 (EM-DAT 2020). ${ }^{2}$ Furthermore, climate change is expected to increase sea levels and the frequency and intensity of floods, globally and in Southeast Asia (World Bank 2014; IPCC 2014). Vietnam has lost 1-1.5\% of GDP annually between 1989 and 2008 due to natural disasters, which hinders the social and economic development of the country (World Bank 2010). To name a few, typhoon Xangsane struck 15 provinces in the central region in 2006 and caused USD 649 million in damage; floods in 2008 affected north and central Vietnam and caused USD 479 million in damage; and typhoon Ketsana swept through central Vietnam in 2009 killing 163 people and causing a total economic loss of USD 785 million (EMDAT 2020).

This paper contributes to the limited micreconomic evidence for disaster impacts on firm growth in labor, capital, and sales using the Enterprise Census data (2000-2014). Specifically, we extend the literature on the determinants of firm growth to incorporate natural disasters as exogenous shocks. We then estimate linear dynamic firm growth models by the Blundell and Bond (1998) system generalized method of moments (system GMM) to identify the growth impacts of storms and floods. System GMM has the advantage that it deals with potential measurement error and endogeneity for variables in the model as well as the weak instrument problem. For floods, we find significant positive impacts on labor growth and capital growth and significant negative impacts on sales growth. We observe some evidence of significant positive lag impacts on labor growth and significant negative lag impacts on sales growth. Moreover, we find significant positive impacts of storms on capital growth and sales growth in the same year as storms strike only with the economic damage measure. Furthermore, we confirm that firm growth depends on firm size and financial constraints and decreases with firm age.

Moreover, this paper makes the first attempt to directly verify the performance of three different disaster measures in the context of micro-level disaster impacts on firms. The three disaster measures are defined based on physical intensities of natural disasters (e.g., wind speed and geographical size affected) and (ad-hoc) damage records (deaths and economic losses). Most studies on disaster impacts have relied on the damage measures which may be endogenous, particularly for cross-country growth studies, because income may be positively related with natural disaster damages (Felbermayr and Gröschl 2014). This is why Felbermayr and Gröschl (2014) built a comprehensive natural disaster database with physical intensities from primary geophysical and meteorological information. They find a substantial negative and robust average impact of disasters on economic growth with the physical disaster indicators, but not with the economic impact indicators. In contrast to the different signs of disaster impacts found at the macro level in Felbermayr and Gröschl (2014), we find mostly consistent signs and magnitudes for disaster impacts on firm growth across the three disaster measures. There are two possible explanations for this difference. First, the endogeneity concern of the economic damage disaster measure is much smaller in our within country study than in a cross-country study with substantial heterogeneity in GDP and reporting of damages. Second, we focus on disaster impacts in the manufacturing sector only while Felbermayr and Gröschl (2014) studied the impacts of disasters on the whole economy. Disaster impacts are likely to differ across economic sectors.

The paper is organized as follows. Section 2 reviews the literature on the impacts of natural disasters with a focus on indirect costs. Section 3 introduces the Enterprise Census

$\overline{2}$ See "Appendix 3" for maps of Vietnam with varying flood risks and storm risks across regions. 
data and the disaster databases used for the analysis. Section 4 reviews the literature on the determinants of firm growth, specifies the growth models for estimation, and presents the estimation results for firm growth and some robustness checks. And Sect. 5 concludes.

\section{The Economic Impacts of Natural Disasters}

This paper is closely related to the literature on the economic impacts of natural disasters, especially the indirect economic consequences of natural disasters. We review the literature below. $^{3}$

The immediate consequences of disasters include mortality, morbidity, loss of physical infrastructure such as roads, telecommunication, and utility services, damages to residential housing and other buildings and their contents, as well as capital stock and inventories of companies. The size of these direct costs is related to both the nature and the physical intensity of the disaster as well as societal resilience against disasters, like early warning systems, evacuation plans, building codes, prevention measures in place, and quality of government institutions (Kahn 2005). Studies on direct natural disaster impacts generally find that such impacts are negative direct costs (Lazzaroni and van Bergeijk 2014).

These initial direct disaster impacts are followed by indirect impacts on the economy. These indirect impacts can be indirect costs, like business interruption costs, but also indirect benefits, for example when businesses that are not directly hit by a disaster take over the reduced supply from businesses with production impaired by the disaster (Hallegatte and Przyluski 2010). Moreover, during the recovery process some firms may experience increased demand which is met by increasing production. An example is the construction sector which often is in high demand when damaged properties need to be repaired.

The theory regarding disaster impacts on firm growth is ambiguous. Standard neoclassical growth models with exogenous technical progress predict a more rapid capital accumulation after the destruction of capital caused by a natural disaster (Noy and Nualsri 2007). This is reflected in higher growth rates which sustain temporarily until new steady state balanced growth is reached.

Growth theories with endogenous technical change result in mixed predictions of growth implications of disasters. Endogenous growth models with increasing returns to scale in production predict that technological change is increasing in the stock of human or physical capital, which implies lower growth after disasters reduce these capital stocks (Romer 1986, 1990). In contrast, in line with the creative destruction theory of Schumpeter (1934), there may be a positive effect on long run economic growth when damaged capital stock after a disaster is replaced and upgraded. For human capital, Skidmore and Toya (2002) expect human capital to increase after a disaster to substitute for lost physical capital, which can contribute to growth and ultimately increase physical capital investments. In the short run, natural disasters may trigger reallocation of labor across sectors. For example, Kirchberger (2017) finds evidence for sectoral reallocation of workers as well as significant and persistent wage premia between the agriculture and construction sectors after an earthquake in Indonesia. But labor supply can be reduced if people migrate out of disaster-stricken areas (Belasen and Polachek 2008, 2009). For low-income countries, natural

\footnotetext{
3 See Botzen et al. (2019) for a comprehensive literature review of the economic impacts of natural disasters.
} 
disasters tend to reduce human capital accumulation in the long run (Baez et al. 2010; Cuaresma 2010; McDermott 2012). On the other hand, disasters may spur innovation (e.g., more patenting activities for technologies that mitigate risks) to reduce and cope with the disaster risks which enhances a country's adaptive capacity (Miao and Popp 2014).

The sign and size of the indirect costs, moreover, depend on the nature and physical intensity of the disasters and on the macroeconomic resilience of a society (Noy 2009). The latter depends on a series of economic, social, and political characteristics, such as the level of economic development, financial market development, institutional quality, education attainment, and trade openness (Anbarci et al. 2005; Raschky 2008; Toya and Skidmore 2007; Noy 2009; Cavallo and Noy 2011). Moreover, mixed results may arise from differences in the definitions of disaster costs and the assessment methodologies and approaches used (Hallegatte and Przyluski 2010).

Overall, there is no consensus in the literature about the sign and magnitude of the short- and long-run indirect costs following natural disasters (Klomp and Valckx 2014; Lazzaroni and van Bergeijk 2014). ${ }^{4}$ Specifically, Lazzaroni and van Bergeijk (2014) analyse 64 primary studies published in 2000-2013 on the macroeconomic impact of natural disasters and conclude that disasters have on average an insignificant impact in terms of indirect costs. Similarly, Klomp and Valckx (2014) perform a meta-regression analysis of studies examining the relationship between economic growth per capita and natural disasters using more than 750 estimates in the literature. They instead find a negative genuine effect of natural disasters on economic growth, which is increasing over the period of analysis. Furthermore, they find that climatic disasters in developing countries have the most significant adverse impact on economic growth.

The literature on disaster impacts mostly uses cross-country macroeconomic data for analysis, which may bias estimates for disaster impacts due to the large variations in macroeconomic dynamics and shocks across countries. Instead, a small literature evaluates disaster impacts at county, region, or state level within a country. Strobl (2011) finds negative impacts on growth in coastal counties in the United States with different hurricane severities, but no effect beyond the county level. Noy and Vu (2010) use provincial level data for Vietnam to evaluate the macroeconomic disaster impacts and find that disasters that destroy more property and capital boost the economy in the short-run, while lethal disasters decrease economic production. Rodríguez-Oreggia et al. (2013) find that general shocks, especially from floods and droughts, lead to significant drops in the social indicators for both human development and poverty levels using municipal level data for Mexico.

While the evidence of disaster impacts on economic growth is inconclusive based on macroeconomic aggregate data, little is known about disaster impacts on businesses and business recovery after a disaster (Tierney 2007; Botzen et al. 2019). Firms receive much less attention in the public debate and also in the literature about disaster impacts, compared to households. ${ }^{5,6}$

A few studies examine how natural disasters impact economic growth or firm recovery via supply chain. Using firm level panel data from Worldscope for 53 countries for the

\footnotetext{
${ }^{4}$ Both meta-analyses find some degree of publication bias for a large part of the negative disaster impacts in the literature and the influence of time periods studied.

5 For instance, most disaster aid from governments and international organizations is directed towards households.

6 The literature about disaster impacts on households (e.g., risk coping and consumption smoothing) is rich (Blaikie et al. 2014) but a review of the literature is beyond the scope of this paper.
} 
period 1990-2004, Altay and Ramirez (2010) find that disasters impact all sectors within a supply chain, and damage by windstorms and floods seem to be dramatically different from that of an earthquake. Accordingly, they suggest a supply-chain-wide mitigation strategy rather than a company-specific one, as well as a disaster-specific approach rather than an all-hazard approach for reducing natural disaster risks. Todo et al. (2015) find a positive net effect of supply chain networks on firm recovery after the Kobe Earthquake using firmlevel data for Japan. Carvalho et al. (2016) provide a systematic quantification of the role of input-output linkages as a mechanism for the propagation and amplification of shocks and find that the propagation of the shock over input-output linkages can account for a 1.2 percentage point decline in Japan's gross output in the year following the 2011 Great East Earthquake.

This paper is closely related to a few studies that examine post-disaster firm or plant survival and growth. Leiter et al. (2009) analyse the short run impacts of EU floods in 2000 on firm growth. They find that, in the short run, companies in flooded regions show on average higher growth of total assets and employment than firms in non-flooded regions. The positive effect prevails for companies with larger shares of intangible assets (e.g., $\mathrm{R} \& \mathrm{D}$, patents, software, and trademarks), which are less exposed to floods than tangible assets. But a negative flood effect is observed for firms' productivity (value-added), which declines with an increasing share of intangible assets. They argue that intangible assets are often an outcome of R\&D activities and may act as a multiplier promoting (softening) positive (negative) tendencies.

Both Tanaka (2015) and Cole et al. (2015) analyse the impacts of the Kobe earthquake on industrial plant survival and growth and find evidence against the creative destruction hypothesis. Specifically, Tanaka (2015) finds that surviving plants experience lower employment and value-added growth than plants in areas not directly stricken during the subsequent three years of the Kobe earthquake. Cole et al. (2015) construct a measure of the damages incurred by individual buildings. They show that the damage caused by the Kobe earthquake increases the likelihood of exiting the market for plants that are unproductive, small, young, and employing low-skilled workers, reduces employment and value-added, boosts the birth of new firms in areas with severe damages, but temporarily increases productivity of surviving plants.

While the three studies above focus on single disaster events from developed countries (the EU and Japan), in this paper we analyse the impacts of multiple floods and storms from 2000 to 2014 in Vietnam. This paper has two methodological innovations. First, we pioneer in verifying the performance of three different disaster measures (physical intensities, number of deaths, and economic damage) in the context of micro-level disaster impacts on firms. Second, we obtain more accurate estimates for disaster impacts by applying the Blundell-Bond (1998) system generalized method of moments (GMM), which largely improves upon the commonly used methods (e.g., difference in difference and matching) in the literature by accounting for firm dynamics, endogeneity, and measurement error using lagged values as instruments.

\section{Data Description}

To identify short-run disaster impacts on firm growth, we use the annual Enterprise Census data (2000-2014) matched with three different disaster databases for Vietnam. We describe the datasets below. 


\subsection{The Enterprise Census Data (2000-2014)}

The Enterprise Census data is collected annually by the General Statistical Office (GSO) of Vietnam since 2000. It covers all state-owned, foreign invested firms, private firms with employment sizes above certain thresholds, ${ }^{7}$ and a fraction of randomly sampled private firms with employment below certain thresholds. ${ }^{8}$ Both the thresholds and sampling frames vary across provinces and over time. ${ }^{9}$ However, a sampling weight is not needed because the numbers of firms in the raw Enterprise Census data are similar to those reported in the statistical year books (2000-2014). The Enterprise Census collects information on ownership structure, location, industrial activities, sales, profits, total and fixed assets, employment, wages, debts, investment, depreciation, et cetera. We focus on manufacturing firms.

We first clean the census data for use. "Appendix 1" documents the details of data cleaning. All nominal values except capital and debt are deflated by a 2-digit industry producer price index with 1995 as the base year while capital and debt are deflated by capital deflators.

\subsection{Three Disaster Databases}

We measure disaster severity using the following three different disaster databases: the Emergency Event Database (EM-DAT hereafter), the ifo Geological and Meteorological Events (GAME hereafter) database, and the Dartmouth Flood Observatory (DFO hereafter) database. We focus on floods and storms (typhoons), the two most frequent and destructive natural disasters in Vietnam. ${ }^{10}$

EM-DAT is by far the most widely used database in the literature about estimating disaster impacts, ${ }^{11}$ recording essential core data on the occurrence and effects of over 22,000 mass disasters worldwide from 1900 to the present day. A disaster is recorded in EM-DAT if it satisfies one of the following four conditions: (1) it caused 10 or more deaths, (2) it affected a population size of 100 or more, (3) it led to a declaration of a state of emergency, (4) it led to a call for international assistance. This collection of natural disasters is mostly based on insurance claims or news stories, which are potentially related with large measurement errors. $^{12}$

Storms and floods dominate the most severe natural disasters during 1990-2019 in Vietnam, especially after 2005 in terms of economic damages (EM-DAT 2020). During 2000-2014, EM-DAT records a total of 42 storms and 49 floods in Vietnam with varying (positive) deaths and economic losses (mostly uninsured) (see Table 1). ${ }^{13} 22$ out of the 42

\footnotetext{
7 Although household enterprises are an important contributor to the GDP growth, job creation, and poverty reduction in Vietnam, they are not covered in the census.

8 The sampling is for the questionnaire No. 1A-DTDN of the census. Non-state firms below the thresholds are also surveyed with questionnaire No. 1B-DTDN, which asks less information than No.1A-DTDN.

9 See "Appendix 1" for more about thresholds and sampling frames.

10 Visit http://www.preventionweb.net/countries/vnm/data/ for more about natural disasters in Vietnam.

11 EM-DAT is collected by the center for research on the epidemiology of disasters (CRED), Université catholique de Louvain in Belgium.

12 The database is compiled from various sources, including UN agencies, non-governmental organizations, insurance companies, research institutes, and press agencies.

13 Storms and floods with both zero death and zero damage are dropped. During 2000-2014, EM-DAT also recorded 3 droughts, 4 landslides, and 1 wildfire in Vietnam. These natural disasters affected much smaller geographical scales compared to storms and floods.
} 
storms are associated with other disasters such as floods, rain, and landslides. Most storms and floods affect multiple areas/provinces albeit with varying severities. Some provinces have experienced multiple storms and/or floods in a year.

The disaster measures in EM-DAT are recorded per disaster, capturing the aggregate impact of a disaster on multiple areas with varying intensities and hence fail to reflect such variation in intensities. Felbermayr and Gröschl (2014) highlight two issues with EM-DAT in a cross-country GDP growth regression, namely: both monetary damage and insurance coverage are correlated with GDP per capita, which causes an endogeneity issue for the disaster measures. This endgoeneity in disaster measures is expected to be weaker in a within-country study with more homogeneity in income levels, quality of infrastructure and institutions, and insurance penetration across regions.

In light of the limitation of EM-DAT, we also use the ifo Geological and Meteorological Events (GAME) database (1979-2014). This dataset collects information on various geological and meteorological events (e.g., earthquakes, volcanic eruptions, storms, extreme temperature events, floods, and droughts) from primary data available per $50 \mathrm{~km}$ by $50 \mathrm{~km}$ grid cell on a monthly basis and converts them into natural hazards and disaster events on per country-year basis for the whole world. GAME captures the physical intensity of disaster events, which is exogenous to economic activity (Felbermayr and Gröschl 2014). In this paper, we use the maximum hurricane windspeed from the primary data to measure storms in Vietnam. ${ }^{14}$ During 2000-2014, 165 out of 34,020 observations (per grid cell per month) have maximum hurricane windspeed 64 knots (the minimum wind speed of Saffir-Simpson Hurricane Wind Scale) or higher with affected geographical size larger than $15 \mathrm{~km}^{2} .{ }^{15}$ An alternative for measuring storm severity locally is via tropical storm models, which also have limitations such as sensitivity to local conditions and model assumptions.

GAME also records precipitation per grid cell, ${ }^{16}$ but it could be a poor measure for flood intensity and damage. High precipitation may not cause flooding when adequate flood protection infrastructure is in place. Moreover, the intensity and duration of rainfall, the geographical location, and climate and land-surface characteristics (e.g., topography, geomorphology, type and quality of soils, et cetera) all play important roles in flood occurrence. On the other hand, flood intensity inferred from flood models also suffer from uncertainties such as parameter uncertainty (Koks et al. 2015).

Therefore, to measure flood intensity, we also use the Dartmouth Flood Observatory (DFO) database, a Global Active Archive of Large Flood Events since 1985 collected by the University of Colorado, for a physical intensity measure of flooding. ${ }^{17}$ It detects, maps, measures, and analyses extreme flood events worldwide using satellite remote sensing. Imaging of selected river reaches is used to detect floods and extreme low flow conditions. The database provides information about flood catalog numbers, centroids, area affected outlines and other attribute information such as beginning and end dates of floods,

\footnotetext{
14 There are two primary data sources for wind speed: the International Best Track Archive for Climate Stewardship (IBTrACS) and the Global Surface Summary of Day (GSOD) data.

15 The threshold of $15 \mathrm{~km}^{2}$ is arbitrary. There are 880 observations with non-missing hurricane wind speed data and with grid size above $15 \mathrm{~km}^{2}$. If we increase the threshold to $100 \mathrm{~km}^{2}$, the number of observations reduces to 156, in which 130 observations have maximum hurricane windspeed above 83 knots.

16 Namely the Global Precipitation Climatology Project (GPCP) recorded by the Goddard Space Flight Center of the National Aeronautics and Space Administration (NASA).

17 See http://floodobservatory.colorado.edu/Archives/index.html.
} 
Table 1 The distribution of storms and floods across regions (2000-2014)

\begin{tabular}{|c|c|c|c|c|c|c|}
\hline \multirow[t]{3}{*}{ Region } & \multicolumn{3}{|l|}{ Storms } & \multicolumn{3}{|l|}{ Floods } \\
\hline & GAME & EMDAT & EMDAT & DFO & EMDAT & EMDAT \\
\hline & Windspeed & Death & Damage & Area affected & Death & Damage \\
\hline Red River Delta & 27 & 10 & 14 & 11 & 17 & 9 \\
\hline South East & 2 & 5 & 4 & 16 & 12 & 7 \\
\hline Mekong River Delta & 4 & 8 & 8 & 47 & 42 & 27 \\
\hline North East & 27 & 26 & 18 & 14 & 15 & 4 \\
\hline North West & 1 & 6 & 6 & 2 & 5 & 1 \\
\hline North Central Coast & 15 & 25 & 25 & 21 & 24 & 31 \\
\hline South Central Coast & 19 & 37 & 33 & 23 & 37 & 41 \\
\hline Central Highlands & 8 & 8 & 7 & 5 & 12 & 8 \\
\hline Total & 103 & 125 & 115 & 139 & 164 & 128 \\
\hline
\end{tabular}

The numbers are calculated after converting disaster data to per province/year/month basis; the cutoff values chosen (storms: wind speed 64 knots, death 16, and damage 25 MUSD; flooding: affected area relative to province size 5, death 45, and damage 10 MUSD) are close to their respective medians; and the numbers of observations vary with the cutoff values chosen but the distribution pattern remains

duration in days, number of deaths, monetary damage, population affected, geographical size affected, and main cause. ${ }^{18}$

DFO records a total of 77 floods with a positive number of deaths and damage against 49 floods recorded in EM-DAT between 2000 and 2014 for Vietnam, of which 29 are jointly recorded by both databases with similar death and damage data (when available). ${ }^{19}$ Although there are many missing values in the economic damage in DFO, other variables such as the geographical size affected, flood duration in days, and number of deaths are more complete and credible. We use the geographical size affected by floods as a proxy for flood intensity. The geographical size affected is positively and significantly correlated with other disaster severity measures such as deaths, damage, population affected and flood duration in days. ${ }^{20}$

Overall the three disaster databases overlap partially in identifying the common storms and floods in Vietnam between 2000 and $2014 .^{21}$ The widely reported typhoons by media such as Damrey (September 2005), Xangsane (October 2006), Durian (December 2006), Lekima (October 2007), Ketsana (September 2009), and Haiyan (November 2013) are recorded in both GAME and EM-DAT.

We first convert the disaster data into observations per year per province, ${ }^{22}$ and then match the converted disaster data with the Enterprise Census data (by province and year)

\footnotetext{
$\overline{18}$ Data for the number of deaths and damage are mostly derived from news, governmental, instrumental, and remote sensing sources.

19 The correlation coefficients of the number of deaths and economic damage from the two datasets are above 0.98 .

20 The correlations are calculated after taking logarithmic transformation on these five variables and the coefficients are respectively: 0.53(75), 0.54(34), 0.52(55), and 0.41(77).

21 See "Appendix 2" Table 12 for more detail about the partial overlapping.

22 Data conversion is documented in "Appendix 2". The link for the GAME codebook is: https://www. cesifo-group.de/ifoHome/facts/EBDC/Ifo-Research-Data/Ifo_GAME_Dataset.html.
} 
for analysing disaster impacts on firm growth. Our disaster measures such as deaths and damage are aggregates from multiple stricken areas. Storms and floods in Vietnam often impact multiple provinces (grid cells) with varying intensities. Moreover, there could be multiple storms and/or floods in a year. But firms in the Enterprise Census are observed per year per province (58 provinces and 5 municipalities ${ }^{23}$ over a span of 15 years).

For the GAME primary data, we first match grid cells to provinces based on the latitudes and longitudes of the grid cells to identify which provinces had storms during 2000-2014. For disasters recorded in EM-DAT and DFO, we extract the locations using the provided information on impacted areas. ${ }^{24}$ For provinces with multiple disasters in a year, we then choose the most severe one in terms of physical intensities, deaths, and/or economic damage. In addition, we also calculate the frequency of severe disasters in a year. After conversion, the same disaster is observed on firms from (multiple) stricken provinces. ${ }^{25}$

Table 1 shows the distribution of converted storms and floods across regions in Vietnam. ${ }^{26}$ The numbers reflect the degree of exposure as they reflect both the frequency of and/or the geographical size affected by storms and floods. ${ }^{27}$ The patterns of the flood and storm risks across regions are largely consistent based on the numbers of storms and floods from the three disaster datasets. The Red River Delta, South Central Coast, and North Central Coast are prone to both floods and storms. The flood risk is most severe in Mekong River Delta. The flood and storm risks in North West, South East, and Central Highlands are relatively low compared to other regions.

We include both flood and storm measures in the growth models for two reasons. First, although storm rainfalls often trigger floods, EMDAT shows that there are also many floods caused by heavy rains in Monsoon seasons in Vietnam. Even if some floods are triggered by storms, they often impact different areas. Another motivation for including separate storm and flood variables in the model is that, storms and floods may have different impact channels. For example, wind damages mainly affect the outside of buildings, while flood waters also damage inventory, machinery and equipment. Therefore, we define flood and storm dummies per year at the provincial level based on physical intensities, number of deaths, and economic damage. The first storm dummy $\left(\mathrm{STM}_{1}\right)$ is defined based on the maximum wind speed from the GAME primary data and is equal to 1 if the storm wind speed is 64 knots or higher with the stricken area at least $10 \%$ of the provincial size and 0 otherwise. ${ }^{28}$ The second and third storm dummies $\left(\mathrm{STM}_{2}\right.$ and $\left.\mathrm{STM}_{3}\right)$ are defined based on casualties and economic damage from EM-DAT. STM 2 is equal to 1 if the number of deaths caused by a storm is above 16 and 0 otherwise. $\mathrm{STM}_{3}$ is equal to 1 if the estimated direct damage is above USD 25 million (hereafter MUSD) and 0 otherwise. ${ }^{29}$ We define flood dummies similarly using DFO and EM-DAT. FLD 1 is equal to 1 if the ratio of the

\footnotetext{
23 The 5 municipalities are centrally-controlled cities (Hanoi, Hai Phong, Da Nang, Ho Chi Minh, and Can Tho) and have special status equal to the provinces.

24 The provided list of areas hit could be incomplete.

25 Note that the values of the disaster measures for the same disaster are the same across provinces directly hit with EM-DAT/DFO but different from GAME primary data.

26 See Fig. 1 in "Appendix 3" for a map of Vietnam with regions.

27 The number increases with the number of provinces in a region hit by the same storm with wind speed/ death/economic damage above their respective chosen cutoff values.

28 We transform the monthly data from grid cell level to provincial level by taking the average of wind speed weighted by cell sizes in a province.

29 The median nonzero death toll and damage by storms in Vietnam are 17 and 21 MUSD.
} 
geographical size affected over province size is above 5 and 0 otherwise (DFO). ${ }^{30}$ The second flood dummy $\left(\mathrm{FLD}_{2}\right)$ is equal to 1 if the number of deaths recorded in EM-DAT are above 45 and 0 otherwise, while the third flood dummy $\left(\mathrm{FLD}_{3}\right)$ is equal to 1 if the estimated economic damage in EM-DAT is above 10 MUSD and 0 otherwise. ${ }^{31}$

Table 2 presents the correlations of the three storm dummies and three flood dummies. The storm dummy defined based on maximum hurricane wind speed $\left(\mathrm{STM}_{1}\right)$ is positively and significantly correlated with the storm dummies defined based on death and damage $\left(\mathrm{STM}_{2}\right.$ and $\mathrm{STM}_{3}, 0.145$ and 0.196 respectively). Similarly, the flood dummy defined based on geographical size $\left(\mathrm{FLD}_{1}\right)$ is positively and significantly correlated with the two flood dummies defined based on death and damage $\left(\mathrm{FLD}_{2}\right.$ and $\mathrm{FLD}_{3}, 0.182$ and 0.265 respectively). But the correlation coefficients between $\mathrm{STM}_{2}$ and $\mathrm{STM}_{3}$ and between $\mathrm{FLD}_{2}$ and $\mathrm{FLD}_{3}$ from EM-DAT are much larger ( 0.797 and 0.623 respectively). This implies that there is only some overlap in the storms and floods identified from the three data sources. ${ }^{32}$ Moreover, the storm dummy defined using GAME shows a negative and significant correlation with the flood dummies. ${ }^{33}$ The storm dummies defined from EM-DAT exhibit positive and significant correlations with all three flood dummies $\left(\mathrm{FLD}_{1}\right.$ and $\left.\mathrm{FLD}_{2}\right)$, which suggests that some storms (recorded in EM-DAT) are associated with floods.

\subsection{Summary Statistics for Firm Sizes, Firm Growth, and Disaster Dummies}

Firm growth is difficult to predict and highly heterogeneous across firms. The choice of firm growth measures depends on specific research topics, data availability, and data quality. Firm size is most commonly measured by employment, total sales, value added (VA), and total assets (Weiss 1998; Delmar 2006). Using employment as a size measure facilitates comparison across industries. Sales growth may mirror best the short- and long- term changes in the firm with the risk of overstating the size of a firm as sales reflect both the value-added of a company and external shocks (e.g., on input prices). Capital accumulation may be problematic for industries with a large share of intangible assets. Financial measures may contain larger measurement errors caused by deflators and/or are prone to manipulations, compared to employment. In our data, VA is not directly reported but can be calculated as the sum of labor costs, profits, and depreciation. Therefore measurement error in VA could be larger than the directly reported sales. Therefore in this paper we focus on labor growth, capital growth, and sales growth, which are calculated as the log difference in firm sizes in two consecutive years (i.e., relative growth).

Table 3 presents the statistics for firm growth rates, firm sizes, age, and storm and flood dummies, which are produced using the cleaned unbalanced panel data with at least 5 years of data. The three size measures are highly positive correlated. ${ }^{34}$ Among the growth measures, the mean and variation are the lowest for labor growth and the highest for sales

\footnotetext{
30 This flood intensity measure also has its limitations, for instance a flood that affects a large geographical area may cause few deaths and little economic damage. But this measure shows positive and significant correlation with death and damage ( 0.3 and 0.6 respectively).

31 The median number of deaths and damage by flooding in Vietnam are respectively 34 and 10 MUSD.

32 This overlap may vary with the cutoff values chosen for defining disaster dummies.

33 We have no clear explanation for this.

34 The correlation is 0.8 between labor and sales, 0.74 between labor and assets and 0.84 between sales and assets.
} 
growth. But the correlations among the three growth measures are much smaller. ${ }^{35}$ Around $7-11 \%$ of the observations are located in provinces with storms and floods in a period of 15 years.

\section{The Determinants of Firm Growth and the Estimation Results for Firm Growth Models}

In this section, we briefly review the literature on the determinants of firm growth, construct our firm growth models, and present the estimation results of the growth models.

\subsection{The Determinants of Firm Growth}

The determinants of firm growth have been studied in various disciplines, including economics, strategy, psychology, network theory, and innovation. Zhou and de Wit (2009) provide an integrated analysis on the determinants of firm growth from different disciplines and classify them into three dimensions: individual (e.g., entrepreneurial personality traits, entrepreneurs' growth motivation, technical knowledge, and experience), and organizational (e.g., firm size, age, market orientation, availability of financial capital, and firm's scalability or its preparedness to grow) and environmental determinants. We focus on the organizational determinants in this paper.

The firm growth model is built based on the empirical literature of firm growth, firm size and age. According to Gibrat's Law, firm growth is independent of initial size. But the evidence for Gibrat's Law is mixed. Hall (1987) finds evidence for Gibrat's Law, while Evans (1987) rejects Gibrat's Law for large US manufacturing firms. Cabral (1995) shows that the growth rate is lower for large firms than small firms. On the other hand, Bentzen et al. (2012) find a positive correlation between firm size and firm growth for Danish firms for the period between 1990 and 2004. For firm age, the negative dependence of growth rate on age appears to be a robust feature of industrial dynamics (Coad 2007a).

The autocorrelation of growth rates reflects firms' growth process and implies a rejection of Gibrat's Law if the autocorrelation is significant. But the number of relevant lags considered varies across studies, ranging from one lag to seven lags (Coad 2007b). There

Table 2 The correlations of storm and flood dummies. Source: EM-DAT, DFO, and GAME (2000-2014)

\begin{tabular}{lclllll}
\hline & $\mathrm{STM}_{1}$ & $\mathrm{STM}_{2}$ & $\mathrm{STM}_{3}$ & $\mathrm{FLD}_{1}$ & $\mathrm{FLD}_{2}$ & $\mathrm{FLD}_{3}$ \\
\hline $\mathrm{STM}_{2}$ & $0.145^{*}$ & 1.000 & & & & \\
$\mathrm{STM}_{3}$ & $0.196^{*}$ & $0.797^{*}$ & 1.000 & & & \\
$\mathrm{FLD}_{1}$ & $-0.037^{*}$ & $0.115^{*}$ & $0.100^{*}$ & 1.000 & & \\
$\mathrm{FLD}_{2}$ & $-0.009^{*}$ & $0.289^{*}$ & $0.271^{*}$ & $0.182^{*}$ & 1.000 & \\
$\mathrm{FLD}_{3}$ & $0.017^{*}$ & $0.064^{*}$ & $0.124^{*}$ & $0.265^{*}$ & $0.623^{*}$ & 1.000 \\
\hline
\end{tabular}

$* p<0.05$

\footnotetext{
35 The correlation is 0.26 between labor growth and sales growth, 0.01 between labor growth and asset growth and 0.05 between sales growth and asset growth.
} 
Table 3 Summary statistics for key variables. Source: Vietnam Enterprise Census Data (balance sheet), GAME, EMDAT, and DFO (2000-2014)

\begin{tabular}{|c|c|c|c|c|c|c|}
\hline Variable & $\mathrm{N}$ & Mean & Median & SD & Min & Max \\
\hline Growth (employment growth) & 179,466 & -0.00 & 0.00 & 0.38 & -1.61 & 1.61 \\
\hline Growths (sales growth) & 165,104 & 0.06 & 0.05 & 0.63 & -2.75 & 3.04 \\
\hline Growth (capital growth) & 177,566 & 0.06 & -0.01 & 0.64 & -3.23 & 3.48 \\
\hline $\operatorname{lnL}$ (employment, in log) & 182,010 & 3.83 & 3.64 & 1.57 & 0.00 & 11.35 \\
\hline $\operatorname{lnS}$ (sales, Million VND, in log) & 182,010 & 8.45 & 8.41 & 2.16 & -0.58 & 16.75 \\
\hline lnK (total assets, Million VND, in log) & 182,010 & 8.48 & 8.33 & 1.84 & 2.12 & 16.02 \\
\hline Age & 182,010 & 9.29 & 7.00 & 7.89 & 1.00 & 70.00 \\
\hline $\mathrm{STM}_{1},=1(0)$ if wind speed $\geq(<) 64$ knots & 182,010 & 0.09 & 0 & 0.28 & 0 & 1 \\
\hline $\mathrm{STM}_{2},=1(0)$ if total death $>(\leq) 16$ & 182,010 & 0.07 & 0 & 0.26 & 0 & 1 \\
\hline $\mathrm{STM}_{3},=1(0)$ if total damage $>(\leq) 25 \mathrm{MUSD}$ & 182,010 & 0.08 & 0 & 0.27 & 0 & 1 \\
\hline $\begin{array}{l}\mathrm{FLD}_{1},=1(0) \text { if affected geographical size } \\
\text { over province size }>(\leq) 5\end{array}$ & 182,010 & 0.09 & 0 & 0.29 & 0 & 1 \\
\hline $\mathrm{FLD}_{2},=1(0)$ if total death $>(\leq) 45$ & 182,010 & 0.11 & 0 & 0.31 & 0 & 1 \\
\hline $\mathrm{FLD}_{3},=1(0)$ if total damage $>(\leq) 10 \mathrm{MUSD}$ & 182,010 & 0.07 & 0 & 0.25 & 0 & 1 \\
\hline
\end{tabular}

Statistics is reported from an unbalanced panel with at least 5 years of observations. Growth is defined as the $\log$ difference of firm sizes in two consecutive years. $\ln \mathrm{L}$ and $\operatorname{lnK}$ are calculated with the end of previous year values

is a lack of consensus within the empirical evidence for the autocorrelation of firm growth (Coad 2009). For instance, it is positive for US manufacturing (Bottazzi and Secchi 2003), but negative for Italian manufacturing (Bottazzi et al. 2006) and French manufacturing (Bottazzi et al. 2011). Coad (2007b) find negative autocorrelation of annual growth rates for small firms but positive autocorrelation of annual growth rates for large firms for French manufacturing. Further investigation by Coad (2009) shows that the autocorrelation of employment growth varies by firm size. Micro firms tend to exhibit negative autocorrelation (lumpy growth profile), while larger firms tend to show positive autocorrelation with high growth episodes stretching over a longer time horizon.

Financial constraints play a substantial role in shaping and conditioning firm decisions underlying growth and survival (Musso and Schiavo 2008), particularly for small and medium sized firms (SMEs). Financial constraints increase exit probability, hold back investment and innovation, and negatively affect firm growth (Hyytinen and Toivanen 2005; Musso and Schiavo 2008). Lack of access to credit may hinder firms' investment to (fully) capture any growth opportunities. Besides, the effect of financial structure on firm growth is statistically significant and quantitatively important (Rahaman 2011). In the presence of external financing constraints, firms rely more on internal funds to finance growth, but the effect of internal financing on firm growth decreases with an increase in the firm's access to an external bank credit facility. Access to capital is an important factor for the post-disaster recovery of small businesses or microenterprises (Webb et al. 2002; Runyan 2006; De Mel et al. 2012). Moreover, natural disasters may aggravate firms' financial constraints by damaging firms' collateral (i.e., tangible assets) required for borrowing and ultimately affect firm survival and growth.

As discussed in Sect. 2, the sign and magnitude of indirect disaster impacts on firm growth are uncertain, depending on the type and severity of the natural disaster considered, and firm- and industry-specific resilience against natural disasters. 
Finally, other factors may also matter for firm growth, including heterogeneity in firm level productivity and production technologies, R\&D investment, industry- and locationspecific factors (e.g., proximity to demand market and production factors, regional institutional quality, knowledge spillovers, et cetera), macroeconomic factors such as financial crises (Coad 2007a), and individual factors such as entrepreneurs' growth motivation, capability, and background (Zhou and de Wit 2009).

\subsection{The Empirical Specifications of the Growth Models}

Based on the literature on the determinants of firm growth summarized in Sect. 4.1 and the available data described in Sect. 3, we specify our general growth model as follows:

$$
\begin{aligned}
\mathrm{GR}_{\mathrm{i}, \mathrm{t}}= & \mathrm{b}_{0}+\sum_{\mathrm{l}=1}^{\mathrm{L}} \mathrm{b}_{11} \mathrm{GR}_{\mathrm{i}, \mathrm{t}-\mathrm{l}}+\mathrm{b}_{2} \operatorname{Size}_{\mathrm{i}, \mathrm{t}-1}+\mathrm{b}_{3} \ln \operatorname{age}_{\mathrm{i}, \mathrm{t}}+\mathrm{b}_{4}\left(\ln _{\operatorname{age}} \mathrm{i}_{\mathrm{i}, \mathrm{t}}\right)^{2} \\
& +\sum_{\mathrm{l} \geq 0}\left(\mathrm{~b}_{5, \mathrm{l}} * \mathrm{STM}_{\mathrm{i}, \mathrm{t}-1}\right)+\sum_{\mathrm{l} \geq 0}\left(\mathrm{~b}_{6, \mathrm{l}} * \mathrm{FLD}_{\mathrm{i}, \mathrm{t}-1}\right)+\mathrm{b}_{7} \text { FinVars }_{\mathrm{i}, \mathrm{t}-1}+\mathrm{b}_{8} \mathrm{X}_{\mathrm{i}, \mathrm{t}-1}+\eta_{\mathrm{i}}+\mathrm{d}_{\mathrm{t}}+\varepsilon_{\mathrm{i}, \mathrm{t}}
\end{aligned}
$$

$\mathrm{GR}_{\mathrm{i}, \mathrm{t}}$ denotes firm growth (in labor, capital, and sales) in period t. The independent variables include lagged growth rates $\left(\mathrm{GR}_{\mathrm{i}, \mathrm{t}-1}\right)$ up to $\mathrm{L}$ lags, firm size $\left(\mathrm{size}_{\mathrm{i}, \mathrm{t}-1}\right)$, $(\log )$ firm age $\left(\ln \mathrm{age}_{\mathrm{i}, \mathrm{t}}\right)$, storm and flood dummies $\left(\mathrm{STM}_{\mathrm{x}}\right.$ and $\left.\mathrm{FLD}_{\mathrm{x}}\right)$ and their appropriate lags, financial variables that capture financial constraints and growth opportunities to some extent (e.g., cash flow to total assets ratio CFK, the ratio of liquid assets and short-term investment to total assets CKK, and total liability to total assets ratio DAR and the square term DARsq), any other available time-varying controls $X_{i, t-1}$ related to firm growth (e.g., the share of female workers, $(\log )$ mean wage per worker and investment rate IKx), a time invariant individual effect $\left(\eta_{i}\right)$, and year dummies $\left(d_{t}\right)$ controlling for common macroeconomic patterns. Finally, $\varepsilon_{i t}$ is an i.i.d error term capturing any other unexplained effects.

Since most storms and floods in Vietnam occur between August and November in a year, the impact of storms and floods on firm growth may extend to multiple years. Therefore, we also include lagged disaster dummies into the growth models. For instance, the one-lag storm (flood) dummy indicates whether there is any storm (flood) occurred one year ago and its coefficient captures whether or not it has lingering impacts on current growth compared to firms in provinces without any disaster.

Although the occurrence of storms and floods are exogenous for firms, disaster measures may still be endogenous. For instance, floods tend to be slow-onset events (except flash floods) and allow firms to take actions to reduce disaster damage. Moreover, firms located in regions more prone to storms and/or floods may invest more to prevent and reduce damage. But we argue that this is less concerning for our disaster measures for three reasons. First, the heterogeneity in the investment in disaster prevention across firms can be captured to some extent by the fixed effects and time trend in the growth models (Elliott et al. 2015). Second, our disaster variables are dummies, which are less prone to endogeneity compared to the damage measures. Third, flood risks are more evenly distributed across regions in Vietnam. For typhoons/storms, the World Bank report (2010) shows that "although the frequency of typhoons appears to be fairly stable over time, the pattern of typhoon events (Beaufort Categories 12 and 13) shows two distinct cycles of peak typhoon activity followed by approximately a decade of zero typhoons. Between 1995 and 2004 Vietnam did not experience any direct typhoon hits on the mainland. Since 2005 there have been 6 typhoons (an average of 1.5 events per year) and 2006 was the worst year on record with 4 category 13 typhoons." Belasten and Polachek (2008) made a similar 
argument that each hurricane event is exogenous and unpredictable in that the exact timing and path of a hurricane cannot be determined a priori, nor can the degree of damage. This means the local disaster risk is less likely to influence location decisions of firms and their investments in disaster prevention. In fact, the main driving force of firms' location choice remains the primacy of economic considerations such as the expansion into new markets or the exploration of new supplies (Linnenluecke et al. 2011). Also, the difference-in-Hansen tests fail to reject the validity of the storm and flood dummies and their lags in the models. Therefore, the storm and flood variables in our growth models are exogenous.

Financially constrained firms have difficulties in financing for value-increasing projects, which ultimately affects firm growth (Ayyagari et al. 2008). But financial constraints are not directly observed. The empirical literature on financial constraints use either indirect proxies (such as having a credit rating or paying dividends or not) or one of the three popular financial constraint indices based on linear combinations of observable firm characteristics [e.g., the Kaplan-Zingales, Whited-Wu, and Hadlock-Pierce indices, see Farre-Mensa and Ljungqvist (2016)]. Apart from firm size and age, we include in our empirical growth models a few indirect proxies for financial constraints such as cash flow to total assets (CFK), share of liquid assets and short-term investment in total assets (CKK), and total liability to total assets ratio (DAR) and its squared term (DARsq) ${ }^{36} \mathrm{CFK}$ reflects firm profitability and growth opportunities. In an imperfect market with frictions, cash flow matters for firm investment and firm growth. CKK may be highly positively correlated to cash holdings and can serve as a proxy for cash holdings. Denis and Sibilkov (2010) show that greater cash holdings of constrained firms are a value-increasing response to costly external financing. Financially constrained firms hold more cash in order to undertake valueincreasing projects that might otherwise be bypassed without sufficient cash holdings. Firms with higher leverage and cash holdings are likely to be financially more constrained and have lower growth, while firms with more cash flow may be less constrained and have higher growth.

Investment rate (IKx) captures growth opportunities and is expected to affect firm growth positively. Both the share of female workers (female) in total employment and (log) firm mean wage per worker (lnmwage) may reflect both firm-level and industry level differences in labor productivity, number of working hours, production technologies, and capital intensities, and thereby impact firm growth.

Table 4 presents the summary statistics for the financial variables and other variables related to firm growth. The investment rate (IKx) is heavily right skewed with a median of $7 \%$, much lower than its average of $30 \%$, implying that most firms have small investments and only a few firms undergo very large investments. The (end of year) liability to total asset ratio (DAR) is also high with an average of $49 \%$, which could be because it includes both short and long term liabilities from formal and informal financing sources. We observe a negative cash flow for $19.6 \%$ of the observations. The share of liquid assets and short term investment in total assets (CKK) is high with an average of 59\%, which may reflect firms' limited borrowing capacity as borrowing in Vietnam often requires collateral. The average share of female workers is around $40 \%$ but with large variations across industries. For instance, the shares of female workers are the highest for industries related to wearing apparels (76.3\%) and tanning and dressing of leather products (67.2\%), and

\footnotetext{
36 Most literature on financial constraints use (long-term) debt asset ratio and cash asset ratio to approximate financial constraints, which are not available in the Enterprise Census data. Instead, we use total liability to asset ratio.
} 
the lowest for basic metal (20.3\%) and machinery and equipments (21.2\%). While the log mean wage per worker is the highest in machinery and equipment and the lowest in wood and wood products production.

With $b_{11} \neq 0$, firm growth is autocorrelated and the growth models become dynamic models. To estimate the dynamic models with fixed effects, we need to take the first difference of the equation to remove the fixed effects. The lagged growth and size variables after first differencing are endogenous as they are correlated with the differenced error term. With growth being autocorrelated, past firm growth rates (with appropriate lags) affect current firm growth rates (relevancy), but not the current error term in the growth models (validity). Therefore, past growth rates can be used as instruments for the endogenous variables. To consistently and efficiently estimate the dynamic growth models, we apply the system generalized method of moments (sys-GMM) proposed by Blundell and Bond (1998). ${ }^{37}$ System GMM accounts for endogeneity and measurement errors in the variables by using lagged values as instruments and overcomes the weak instrument problem (in case of highly autocorrelated growth). But one caveat of system GMM is instrument proliferation. While theoretically adding additional moment conditions may improve the asymptotic efficiency of GMM, Ziliak (1997) has found severe downward bias in GMM as the number of moment conditions expands, which outweighs the gains in efficiency. Roodman (2009a) also shows that a large instrument collection overfits endogenous variables and weakens the Hansen test of the instruments' joint validity. One strategy to avoid instrument proliferation is to use only certain lags instead of all available lags for instruments. We use the Arellano-Bond autocorrelation tests to guide our selection of lagged values as instruments and the Hansen $\mathrm{J}$ tests to test the joint validity of the lagged instruments.

\subsection{The Estimation Results for the Firm Growth Models}

We report the estimation results for the growth models in Table 5 (disaster impacts) and in Table 6 (for other variables, full sample). Specifically, Table 5 presents the coefficient estimates for disaster dummies defined based on physical intensities (GAME and DFO), and casualties and economic damage (EM-DAT).

The final specifications of the three growth models vary slightly. For instance, the number of lagged disaster dummies included and the length of autocorrelation vary across different specifications. ${ }^{38}$ We use the following instruments to estimate the growth models: the appropriate (up to five) lags of growth and firm size variables, disaster dummies and their lags, year dummies, firm age, and all other variables included in the model. To reduce the risk of overfitting bias, we limit the number of lags to five for endogenous variables. But the estimation results are robust to the inclusion of extra lagged instruments. In all cases, both the AR(2) test and the Hansen over-identifying test are not rejected, indicating the validity of the (lagged) instruments used and a good fit of the models to the data.

The coefficients of the storm and flood dummies capture the average impacts of disasters on firm growth for firms in provinces stricken by storms and floods, compared to firms in provinces not stricken by storms and floods. Therefore these average disaster impacts also capture the spillover effects of firms not hit directly and located in the same provinces.

\footnotetext{
37 Roodman (2009b) illustrates in detail how to implement system GMM estimation in Stata.

38 Lagged storm and flood dummies with coefficients close to zero and insignificant are dropped from the final specifications and Chi-square tests are not rejected as a result of dropping them.
} 
The coefficients of the flood dummies and their lags are positive in labor growth and capital growth but are negative in sales growth. We observe a similar pattern for the storm dummies but the number of (lagged) storm dummies with significant coefficients is much smaller compared to the (lagged) flood dummies. Overall, storms and floods appear to have generated positive demand shocks for labor and capital (of similar magnitude) for recovery and reconstruction purposes but have disrupted sales in the short run. We illustrate the estimation results in detail below.

\subsubsection{Impact on Labor Growth}

The coefficients of the three storm dummies $\left(\operatorname{STM}_{\mathrm{x}=1,2,3}\right)$ and the three flood dummies $\left(\mathrm{FLD}_{\mathrm{x}=1,2,3}\right)$ are close to zero and insignificant. Therefore, storms and floods do not have a significant immediate impact on labor growth in the same year as their occurrence. But storms appear to have a positive and significant lagged impact on labor growth (around $1.1 \%) 2$ years later with the economic damage measure, or 3 years later with the physical intensity and death measures. Flooding increases labor growth significantly in the next three years, especially with the physical intensity and economic damage measures. Specifically, flooding stimulates post-flood labor growth in stricken provinces by $1.7-2.7 \%$ one year later and $0.8-1.5 \%$ three years later.

\subsubsection{Impact on Capital Growth}

All coefficients of the three storm dummies and their lags are positive, but most are close to zero and insignificant except for the economic damage measure $(0.023$ with $p$-value 0.00 for $\mathrm{STM}_{3}$ and 0.015 with $p$-value 0.05 for $\mathrm{L} . S T M_{3}$ ). Storms often damage and destroy physical capital (e.g., factories, machinery and equipment, raw materials, and inventories). The value of the physical capital destroyed is highly correlated with the economic damage reported. Therefore, we expect a larger and stronger relationship between the economic damage measure and the growth in monetary values than the other two disaster measures. The coefficients of the flood dummies and their first and second lags are positive and mostly significant. Therefore flooding also stimulates capital growth in flood-stricken provinces in the short run (within three years), which is stronger than the impact of storms.

The positive (lagged) impacts on the growth of capital and labor in disaster stricken provinces could be due to post-disaster recovery and reconstruction. The short-run impacts of cyclones and tornados on (local) labor growth in the literature are negative, but vary across industrial sectors (e.g., Belasen and Polachek 2008, 2009; Ewing et al. 2003, 2009). Storms and floods may increase the demand for capital and labor of firms hit directly to resume production, and of firms not hit directly taking over some of the production shortfalls from firms hit directly. Similarly, when a natural disaster strikes, it damages physical capital, and devastated capital may not only be replaced, but upgraded using more advanced (up-to-date) technologies. Further, older infrastructure and buildings are more prone to damage from disasters, and the reinvestment and replacement of such facilities may take place. We can view this post-disaster input growth as 'reversing to the mean'.

But it takes time to adjust capital and labor for recovery and reconstruction. Since most storms and floods in Vietnam occur between August and November, it is not surprising to find limited evidence of immediate impacts but more evidence of lagged impacts on firm growth in capital and labor. 
Table 4 Summary statistics for financial variables and other variables related to growth. Source: Vietnam enterprise census data (balance sheet) (2000-2014)

\begin{tabular}{lllllll}
\hline Variable & $\mathrm{N}$ & Mean & Median & SD & Min & Max \\
\hline IKx & 182,010 & 0.30 & 0.07 & 0.89 & -1.32 & 11.03 \\
DAR & 182,010 & 0.49 & 0.50 & 0.35 & 0.00 & 9.95 \\
CFK & 182,010 & 0.06 & 0.04 & 0.11 & -0.43 & 0.61 \\
CKK & 182,010 & 0.59 & 0.62 & 0.24 & 0.00 & 1.00 \\
femalep & 182,010 & 0.40 & 0.35 & 0.24 & 0.00 & 1.00 \\
Lnmwage & 182,010 & 2.54 & 2.59 & 0.71 & 0.12 & 4.30 \\
\hline
\end{tabular}

Statistics is reported from an unbalanced panel with at least 5 years of observations. IKx is the investment rate of fixed and long-term assets, where investment is calculated as the sum of depreciation and the changes in the fixed assets and long-term investment in a year. DAR is the total liability to total assets ratio, and CFK is the cash flow to total assets ratio, where cash flow is calculated as the sum of net profit and depreciation. CKK is the ratio of liquid assets and short-term investment to total assets. DAR, CFK, and CKK are calculated with the end of previous year values. femalep and lnmwage are the share of female workers in total employment and firm mean wage per worker (in log)

Table 5 Impacts of storms and floods on firm growth

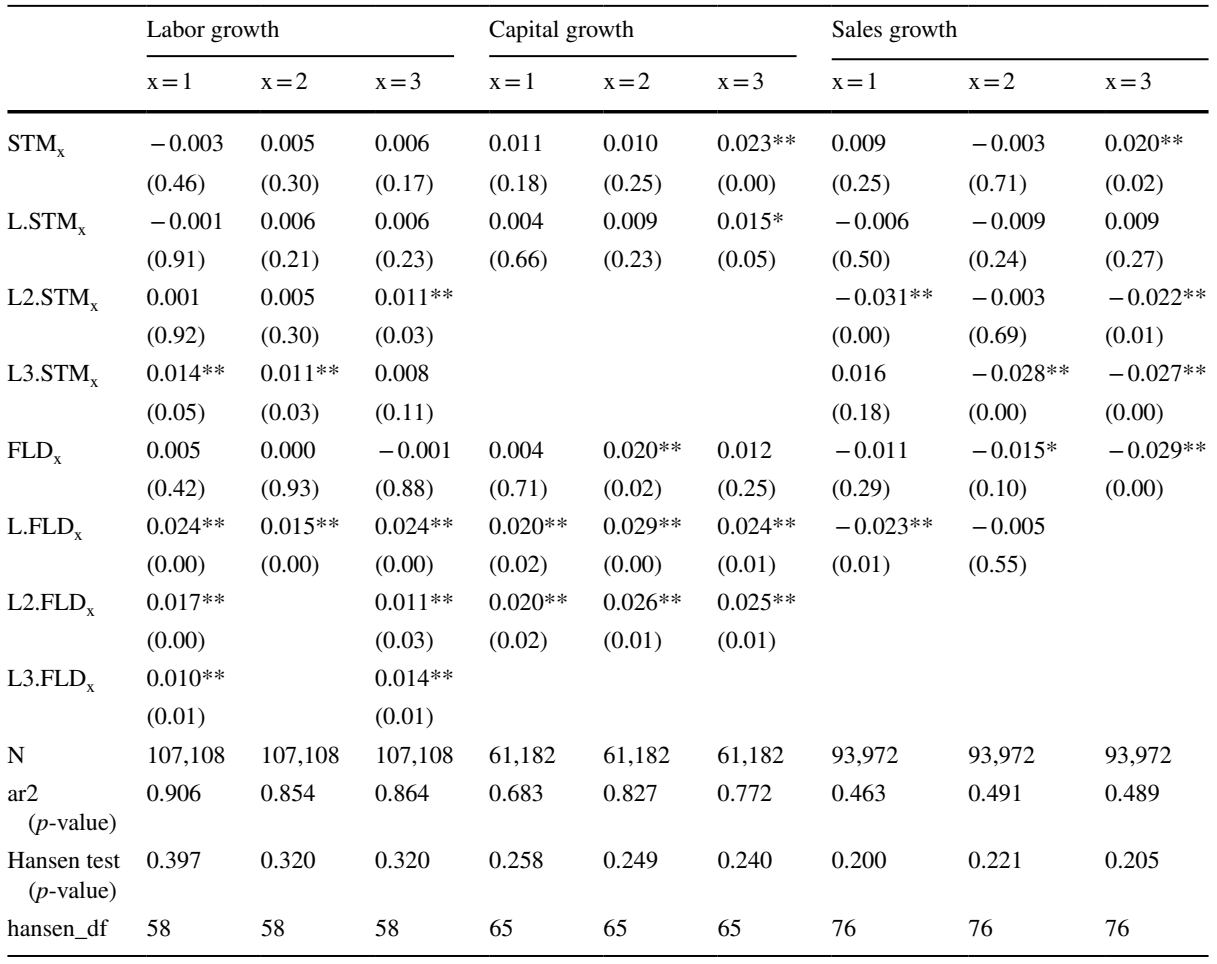

$p$-values in parentheses; $* p<0.10, * * p<0.05$. All specifications include year dummies and fixed effects. Growth models are estimated by system GMM clustered at the firm level. The GMM type instruments include growth and size variables with appropriate lags; IV instruments include disaster (lagged) dummies, year dummies, firm age, lagged financial variables, lagged share of female workers, and lagged (log) mean wage per worker. $\mathrm{STM}_{\mathrm{x}}$ and $\mathrm{FLD}_{\mathrm{x}}$ are storm and flood dummies defined based on physical intensity measures (max. wind speed and geographical area affected, $x=1)$, the number of deaths $(x=2)$, and economic damage $(\mathrm{x}=3)$ 


\subsubsection{Impact on Sales Growth}

Storms have no immediate impact on sales growth with the physical intensity and the number of deaths measures but have a positive and significant immediate impact on sales growth $(0.02$ with $p$-value 0.02$)$ with the economic damage measure. However storms have significant negative lag effects on sales growth after two to three years (ranging from -0.022 to -0.031 ). The coefficients of the three flood dummies and their lags are all negative. Flooding has an immediate significant negative impact on sales growth in the same year but not beyond with the death toll $(-0.015)$ and damage measures $(-0.029)$. Flooding also negatively impacts sales growth one year later $(-0.023$ with $p$-value 0.01$)$ with the physical intensity measure (i.e., geographical area affected).

The negative effects on sales growth could be caused by the disruption of supply chains, sales network, and public infrastructure (e.g., roads, electricity, water, and telecommunication), apart from production disruption. Besides, storms and floods may also cause negative demand shocks. For instance, natural disasters may negatively affect agriculture production and reduce rural household incomes and demand for industrial products (e.g., Sivakumar 2005). Similar to the capital and labor adjustments, it also takes time to recover the disrupted supply chains and the damaged public infrastructure.

Apart from the impacts on surviving firms, natural disasters may force some (e.g., less efficient) firms to go bankrupt (Uchida et al. 2014). But firms may still struggle to stay afloat for some time before exit. Although capital is important for recovery (De Mel et al. 2012), financing for investment may be difficult and time consuming due to financial frictions and loss of collateral by natural disasters in Vietnam. Therefore, these firms may resort to lowering wages first and/or laying off workers later, but ultimately exit the market. This may to some extent explain the stronger evidence for the lagged impact on the growth of labor and capital than the immediate impact, especially for flooding.

Our results are similar to the findings in Leiter et al. (2009) for Europe, namely that positive input growth doesn't lead to positive sales (and output) growth. ${ }^{39}$ Leiter et al. (2009) argued that storms and floods in Europe may induce investment activities in production factors that go beyond the sole replacement of disaster losses and result in a less productive factor composition in the short run. This argument may also be valid in explaining our findings of disaster impacts for Vietnam.

We notice one large difference in the impact of storms on sales growth with the three disaster measures. Specifically, the impact of storms on sales growth in the same year as storms strike is positive and significant (0.02 with $p$-value 0.02$)$ based on the economic damage measure $\left(\mathrm{STM}_{3}\right)$, but is close to zero and insignificant based on physical intensity and number of deaths. This difference cannot be explained by measurement errors and attenuation bias, because the dynamic GMM method tackles measurement errors and endogeneity in the models by using instruments.

To explain this difference, we decompose sales growth across firms of different capital intensity. ${ }^{40}$ The idea is that more capital intensive firms in manufacturing may have more physical capital and be more exposed to storms and floods. The results are reported in "Appendix 4" (Table 14). We find that the positive and significant immediate storm impact with the damage measure comes from labor (low capital) intensive firms only (0.043 with

\footnotetext{
39 Since sales do not fully reflect production, we also check value added growth in the robustness check.

40 We sort firms into three groups (low, medium, and high) based on their capital intensities, similar to Kucera and Sarna (2006). The shares of firms in the 3 groups are respectively 41.4, 35.1, and 23.5 percent.
} 
$p$-value 0.00 for $\mathrm{STM}_{3}$ and 0.027 with $p$-value 0.06 for $\mathrm{L}_{\text {.STM }}$ ). The immediate and lagged one period impacts for firms of medium and high capital intensity are small and insignificant. Noticeably, the negative and significant lagged impact of storms (L2.STM and $\mathrm{L}_{3} . \mathrm{STM}_{3}$ ) on sales growth is the largest (and significant) for medium capital-intensive firms and the smallest (and insignificant) for labor intensive firms.

One explanation for the above findings is that labor-intensive firms may have lower capital adjustment costs and physical damages, hence they can quickly adjust their capital stock and resume their production and sales. The more pronounced negative lagged impact of storms on sales growth for capital intensive firms implies that capital-intensive firms likely need more time to adjust and repair damaged capital and to resume production and sales.

To summarize, we find a significant positive impact of flooding on input growth (labor and capital) and a significant negative impact on sales growth in the short run. Storms have significant positive lag effects on labor growth and negative lag impacts on sales growth up to three years after occurrence. Moreover, the immediate impacts of storms on capital growth and sales growth are positive and significant with the economic damage measure only.

Notably the impacts of storms and floods on firm growth are overall consistent with one another in sign, and also in scale to some extent (with a slight variation in the timing of their impacts), across the three different types of disaster severity measures. This consistent picture of micro level disaster impacts is different from Felbermayr and Gröschl (2014). They found a substantial negative and robust average impact of disasters on growth with the physical intensity measure but a positive (albeit insignificant) impact with the damage measures. But the sign of the impact turns negative (insignificant) for the damage measures when they focused on large disaster events. We also focus on more severe storms and floods in this paper.

There are two possible explanations for this difference of disaster impacts with different disaster measures at the macro and micro level. First, as argued in Felbermayr and Gröschl (2014), cross-country regression studies on disaster impacts using damage measures suffer from endogeneity. This is because both the monetary damages and the quality of damage reporting tend to be higher in rich countries. Hence the damage measures are correlated with GDP. These effects are more important in a cross-country study with substantial heterogeneity in GDP and reporting of damages, and less so in a within country study where these variables would be more homogenous. Besides, the damages reported in EMDAT for Vietnam are aggregated from multiple affected provinces, which reduces the possible positive correlation between the reported damages and the income level and reporting quality across provinces. Second, Feblbermayr and Groschl (2014) studied the aggregate impact of natural disasters on the whole economy, while we focus on the manufacturing sector only. Natural disasters may have different impacts on different sectors, such as agriculture (Sivakumar 2005), finance (Hosono et al. 2016; Klomp 2014), and service (Rosselló et al. 2020). These two arguments may explain to some extent the different results at the macro and micro level.

We are aware that storms and floods are mostly local events and have been shown to have short-run negative effects on local employment, earnings, and the economy, although the overall impact may be fully or partially 'aggregated out' at regional or national level (Ewing et al. 2003; Banerjee 2007; Belasen and Polachek 2008, 2009; Strobl 2011; Bertinelli and Strobl 2013; Elliott et al. 2015; Mohan and Strobl 2017; Del Valle et al. 2018). Therefore, our analysis could benefit from higher frequency information both at the 
spatial and temporal levels. But due to data limitations, our analysis is restricted to per province per year levels.

At the spatial level, the coefficients of our disaster dummies and their lags capture the average disaster impacts for firms in provinces stricken by storms and/or floods compared to firms in provinces without storms and floods. These average impacts also include within province substitution effects experienced by firms that are not directly hit by natural disasters. ${ }^{41}$ Although we are not able to identify the likely heterogenous impacts of floods and storms on areas more disaggregate than the provincial level, we learn more about the aggregated net impacts of a disaster on firms in a province, signaling the important impacts of storms and floods on the aggregate economy in Vietnam. Moreover, the geographical sizes of most provinces in Vietnam are relatively small with a median of $3530 \mathrm{~km}^{2}$. The larger provinces are mostly in Central Highlands, Central Coast, and Northwest of the country and are less populous and have fewer firms (compared to the Red River Delta and South East), although firms in these regions are likely to be more vulnerable to natural disasters.

At the temporal level, although we have no data to show the impact dynamics at a higher frequency level (e.g., monthly or quarterly) like Banerjee (2007) and Mohan and Strobl (2017), we argue that this is not a concern since most storms and floods in Vietnam occur between August and November in a year and the concurrent disaster variables can capture the immediate short run disaster impacts (within 1-4 months, if any) to some extent. Besides, it is also interesting to identify whether disaster impacts last longer than a few months by including lagged disaster dummies at an annual level.

The disaster impact may be spatially correlated as severe storms and floods may hit multiple provinces in Vietnam, albeit with varying severities. This spatial correlation can be addressed to some extent by including fixed effects and by clustering. According to Abadie et al. (2017), clustering is in essence a design problem, either a sampling design or an experimental design issue. With fixed effects, one should cluster if there is heterogeneity in the treatment effects and there is clustering either in the sampling or in the treatment assignment.

The Enterprise Census data we used are not clustered in the sampling, but the treatment assignment may be clustered across multiple provinces stricken by storms and/or floods. Our estimation actually takes care of the possible spatial correlation on the treatment effect. If a disaster affects multiple provinces, the disaster dummy will be equal to 1 for firms in all provinces that are directly stricken, but 0 for firms in other provinces without a natural disaster. Therefore, the coefficient for the disaster dummy actually captures the average impact of the disaster on firms from all stricken provinces. We are aware that the average disaster impact may be heterogenous across the stricken provinces with varying disaster intensities. This provincial level heterogeneity in the disaster impact can be captured to some extent by the fixed effects in the model. Therefore, the impact of the possible spatial correlation is taken care of by the construction of our disaster variables and the fixed effect in the model. Note that it is impossible to cluster at the regional level (with multiple provinces) as we study the impacts of multiple storms and floods over a span of 15 years with varying clusters. Finally, we argue that cross-region spillover effects of storms and floods are less concerning because most firms in Vietnam are clustered in three (Northern,

\footnotetext{
${ }_{41}$ For firms not directly impacted in the disaster-stricken provinces, the spillover effects could be positive if they take over the production shortfalls from firms hit directly and negative if they are in the same supply chain networks as firms hit directly.
} 
Central, and Southern) key economic zones (KEZs) that specialize in different industrial activities (see Figs. 1, 2, 3 in "Appendix 3" for a map of the KEZs). ${ }^{42}$

\subsection{Other Determinants of Firm Growth}

The coefficient estimates for other variables are similar and robust to the disaster measures used in the growth models. Therefore, we report their estimation results once (instead of three times) for each growth measure with disasters defined based on the economc damage in Table 6 (full sample). ${ }^{43}$ Overall the coefficient estimates are consistent in sign with the findings in the empirical literature on firm growth.

\subsubsection{Autocorrelation}

The autocorrelation is up to three lags for both labor growth and sales growth, and up to five lags for capital growth. The autocorrelation coefficients are all negative and significant for labor growth $(-0.21,-0.05$ and -0.01$)$ and negative but insignificant with its first lag for sales growth $(-0.19$ with $p$-value 0.15$)$. For capital growth, the autocorrelation is negative with the first two lags but becomes positive with the latter three lags, although only the autocorrelations with the first lag $(-0.378)$ and the fourth lag $(0.04)$ are significant. However, dropping insignificant lagged growth leads to rejections of the GMM autocorrelation tests and the Hansen overidentification tests. The results show that firm growth in labor, sales, and capital show some degree of negative autocorrelation and hence rapid growth is not persistent in the short run.

\subsubsection{Size and Age}

Firm size matters for firm growth, but with varying signs across the growth measures, rejecting Gibrat's Law. Specifically, labor growth decreases with firm size $(-0.011)$ while capital growth and sales growth both increase with firm size (0.024 and 0.037). The latter observation is consistent with the findings in Bentzen et al. (2012) for Danish firms. Across all three growth measures, firm growth decreases significantly with firm age at an increasing speed, which is more pronounced for large firms.

\subsubsection{Financial Variables}

In our data, CFK, DAR, and IKx significantly increase with firm size and CKK significantly decreases with firm size. Besides, the averages and medians of CFK and DAR are the largest for state-owned firms (SOEs) and the lowest for private firms. The averages and

\footnotetext{
${ }^{42}$ The Northern KEZ focuses on agricultural products and heavy manufacturing, the Central KEZ focuses on marine economy (e.g., seafood, food processing, oil and gas, ship building, logistics, and other hightech industries), while the South KEZ is dedicated to the development of commerce, exports, technology, services, and telecommunications. Among Vietnams' main export sectors, garment and textile manufacturing are concentrated in both the north and south Vietnam, while footwear and furniture manufacturing are concentrated in the south.

${ }^{43}$ We also present the results for small and medium sized enterprises and large firms in Table 6 as a robustness check.
} 
medians of CKK are the highest for private firms and the lowest for foreign firms. ${ }^{44}$ All these variables are lagged once in the growth models.

The coefficients of DAR are negative for all growth measures and significant for labor growth $(-0.024$ with $p$-value 0.00$)$ and sales growth $(-0.072$ with $p$-value). But capital growth significantly decreases with the leverage ratio for large firms with more than 200 employees. The coefficients of CFK are negative and significant for sales growth but positive and significant for capital growth. ${ }^{45}$ Financial constraints matter more for capital investment compared to labor growth and sales growth. The coefficients of CKK are negative and significant for labor growth and sales growth, but positive and significant for capital growth. Capital growth is higher for firms with a low share of fixed assets and long term investment in total assets but it is the opposite for labor growth and sales growth.

Overall, the coefficient estimates for the financial variables confirm that financial constraints play an important role in firm growth.

\subsubsection{Other Variables}

Firm investment rate one year ago has positive and significant impacts on both labor growth (0.009) and sales growth (0.025). This positive relationship is as expected because investment rates reflect growth opportunities. Moreover, capital invested last period often becomes productive this period and may stimulate the demand for labor and ultimately increase production and sales. Finally, we observe that capital growth and sales growth decrease while labor growth increases signficantly with both $(\log )$ mean wage per worker and the share of female workers. Labor growth is faster for firms that pay higher wages or have higher shares of female workers.

\subsection{Robustness Checks}

We perform some robustness checks, including estimating the growth models separately for small and medium sized firms and large firms (Tables 6, 7), pooling storm and flood together, varying the cutoff values for defining the disaster dummies (Table 8), and examining an alternative measure of firm growth, namely value added (VA) growth (Table 9).

\subsubsection{Disaster Impacts for Small and Medium Sized Firms (SMEs) Versus Large Firms}

We first investigate the possible heterogeneous disaster impacts between SMEs and large firms. Here we borrow the definition of SMEs from the Law on Support for Small and Medium-sized Enterprises (SMEs) in Vietnam and define SMEs as firms with an average number of employees no more than $200 .{ }^{46}$

\footnotetext{
${ }^{44}$ CFK and CKK is negatively correlated $(-0.12$ with $p$-value 0.00$)$ for SMEs but uncorrelated for large firms.

45 CFK has small and insignificant coefficients in the labor growth model and is dropped.

46 In this law that became effective on January 1st 2018, SMEs are defined as micro, small, and mediumsized enterprises having no more than 200 employees; or total capital not exceeding VND 100 billion (around 4.4 MUSD); or total revenue not exceeding VND 300 billion (around 13.2 MUSD).
} 
SMEs play an important role in the economy of Vietnam. $83 \%$ of the observations in the Enterprise Census data are SMEs, accounting for $41 \%$ of aggregate output and $26 \%$ of aggregate employment in 2014. Almost $85 \%$ of the SMEs are private firms, whereas almost $60 \%$ of the large firms are state-owned and foreign firms. ${ }^{47}$ Besides, around $48 \%$ of the large firms are located in South East, a region less prone to both storm and flood risks compared to other regions. ${ }^{48} \mathrm{SMEs}$ are also much smaller in total assets and sales and younger than large firms.

Therefore, SMEs and large firms may differ largely in their growth patterns, growth barriers, capital structure, resilience against storms and floods, and other features (e.g., ownership types and locations). The impacts of storms and floods on their growth may be different as well. For instance, SMEs may be less experienced and less resourceful in dealing with natural disasters compared to large and older firms. SMEs may be more labor intensive and have lower shares of tangible assets that are more vulnerable to storms and floods compared to large firms. On the other hand, large firms in Vietnam are more capital intensive and more involved in R\&D activities than SMEs and hence may have a higher share of intangible assets that are less vulnerable to natural disasters.

We estimate the growth models separately for SMEs and large firms. Table 7 presents the coefficient estimates for the disaster dummies of the firm growth models for SMEs and large firms. The rest of the coefficient estimates are reported in Table 6. Overall the impacts of storms and floods on firm growth are different between SMEs and large firms. In most cases the disaster impacts are larger and more persistent for SMEs than for large firms. $^{49}$

\subsubsection{Labor Growth}

Storms have no immediate impacts, but have some significant positive lag impacts on labor growth for both SMEs (two to three years later) and large firms (one year later). The immediate impacts of flooding on labor growth is small and insignificant. For SMEs and large firms, we observe similar positive lag impacts on labor growth one year after flooding, which persist two more years for SMEs.

\subsubsection{Capital Growth}

The impacts of storms and floods on capital growth are different between SMEs and large firms. The flooding impacts are positive and significant for SMEs, but mostly negative and insignificant for large firms. Storms have no significant impacts on capital growth for SMEs

\footnotetext{
47 State-owned firms (also include joint stock corporation with state capital) in Vietnam are dominant and large in strategic sectors and have preferential access to official credits compared to private firms. $70 \%$ of foreign firms are located in South East and another 17.6\% are located in the Red River Delta.

48 Firms' location choice is mainly driven by subnational institutions, infrastructure, proximity to the destination market, the availability of scarce resources (e.g., land access, raw materials, and talent) (Meyer and Nguyen 2005), and industry-level agglomeration benefits (Head et al. 1995), rather than driven by climate risks. The location choice is typically more strategic for FDI firms (more export oriented) than domestic private firms.

49 The results are similar when SMEs are instead defined as firms with total capital not exceeding VND 100 billion.
} 
(except with the economic damage measure), but have significant positive lag impacts on capital growth for large firms (two to three years later) for all three disaster measures.

\subsubsection{Sales Growth}

The impacts of storms and floods are mostly negative on sales growth for both SMEs and large firms, but the patterns are different across the disaster measures. Storms have significant negative lag impacts on sales growth two or three years after their occurrence for SMEs, whereas the impacts are smaller (in absolute term) for large firms in most cases. Flooding reduces sales growth more for SMEs than large firms in the same year and one year later. But we also observe some exceptional cases in which the disaster impacts on sales growth are stronger for large firms than SMEs. For instance, the coefficients of FLD ${ }_{1}$, $\mathrm{STM}_{2}$ and $\mathrm{L}_{2 . S T M}$ are negative and significant for large firms while they are close to zero and insignificant for SMEs.

To summarize, the impacts of storms and floods on firm growth are overall more pronounced and more persistent for SMEs than large firms, regardless of whether they are positive or negative. Large firms may be more experienced and more prepared for recurrent storms and floods and hence experience lower physical damage than SMEs. With potentially more physical damage and lower shares of fixed assets and long term investment in total assets, SMEs are more responsive to storms and floods than large firms in capital and labor adjustments. Besides, the disruption of public infrastructure and sales network caused by storms and flooding reduces the sales growth for both SMEs and large firms.

The coefficient estimates for other variables are mostly of the same signs between SMEs and large firms, albeit with varying scales, except for lagged growth rates (see Table 6). The patterns of autocorrelation in growth differ between SMEs and large firms. For instance, the autocorrelation of labor growth is negative and significant with its first three lags for SMEs, but is significant and negative with its first lag and turns positive and significant with its second and third lags for large firms. The autocorrelation of capital growth is significant and positive up to two lags for large firms, which is opposite to the pattern observed for SMEs. Finally, the autocorrelation is negative and insignificant with its first two lags but turns positive and significant with its third lag for large firms, while they are all negative for SMEs. Firm growth is not persistent, which is more so for SMEs than large firms.

\subsubsection{Grouping Storms and Floods Together Within the Same Year}

Next, we investigate the combined (net) disaster impacts on firm growth by grouping storms and floods together in a year in the same province. The motivation is that storms and floods are often closely related. Tropical storms are often associated with heavy rainfall that may cause flooding and hence it is not easy to separately identify their impacts on firm growth when they occur alongside each other. In this case it is more interesting to study their combined net effects. Table 8 presents the results with the disaster dummies DIS $_{\mathrm{x}}$ equal to one if either the storm dummy $\left(\mathrm{STM}_{\mathrm{x}}\right)$ and/or the flood dummy $\left(\mathrm{FLD}_{\mathrm{x}}\right)$ is equal to one $(\mathrm{x}=1,2,3)$.

The combined disaster impacts obtained are positive and persistent for labor growth and capital growth, which is true across all three disaster dummies defined based on different measures. Although there are no immediate impacts on labor growth, the significant positive disaster impacts on labor growth last for three years. Storms and floods stimulate 


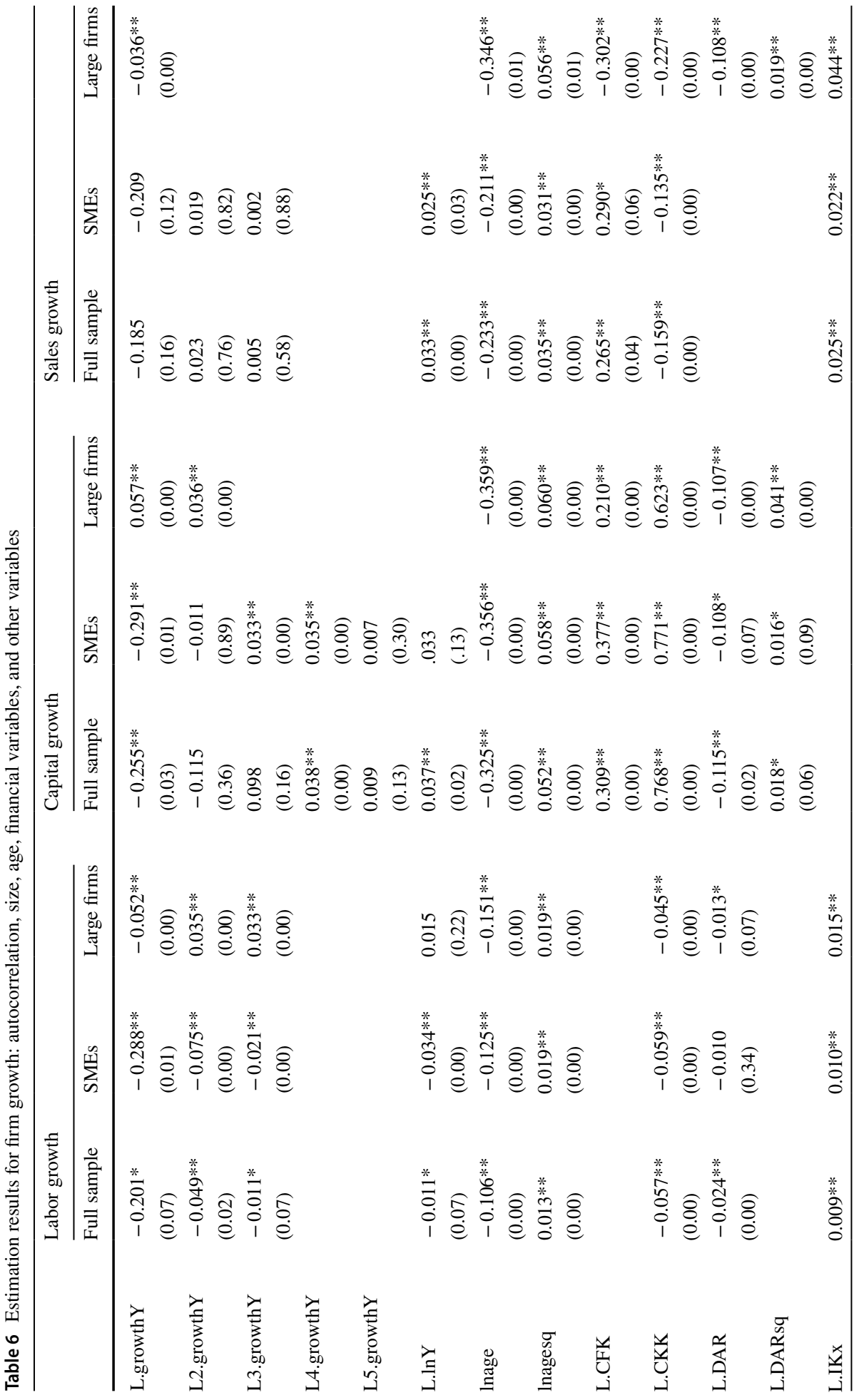




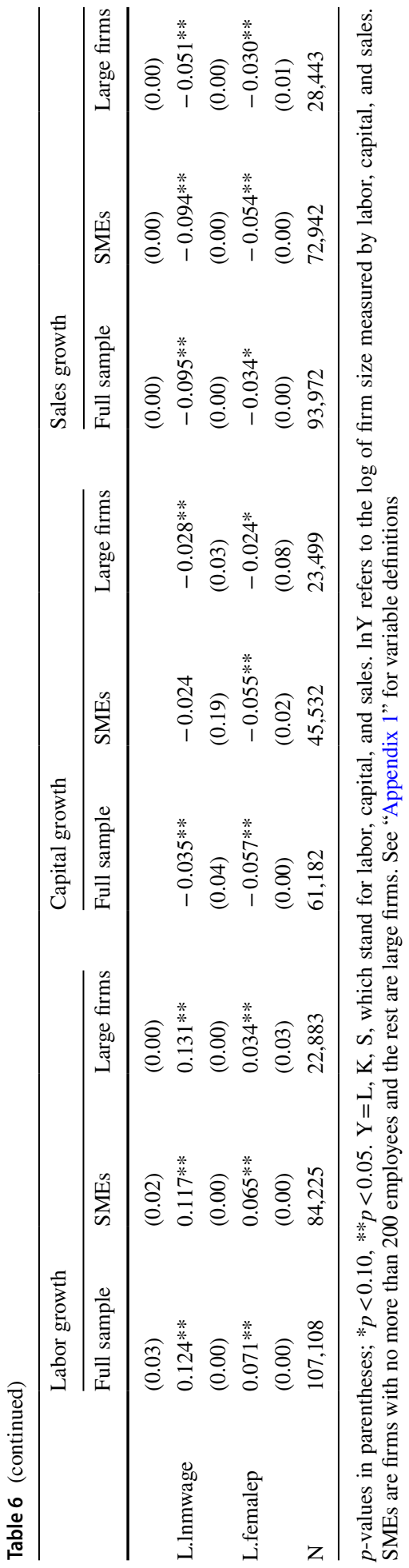


Table 7 Impacts of storms and floods on firm growth

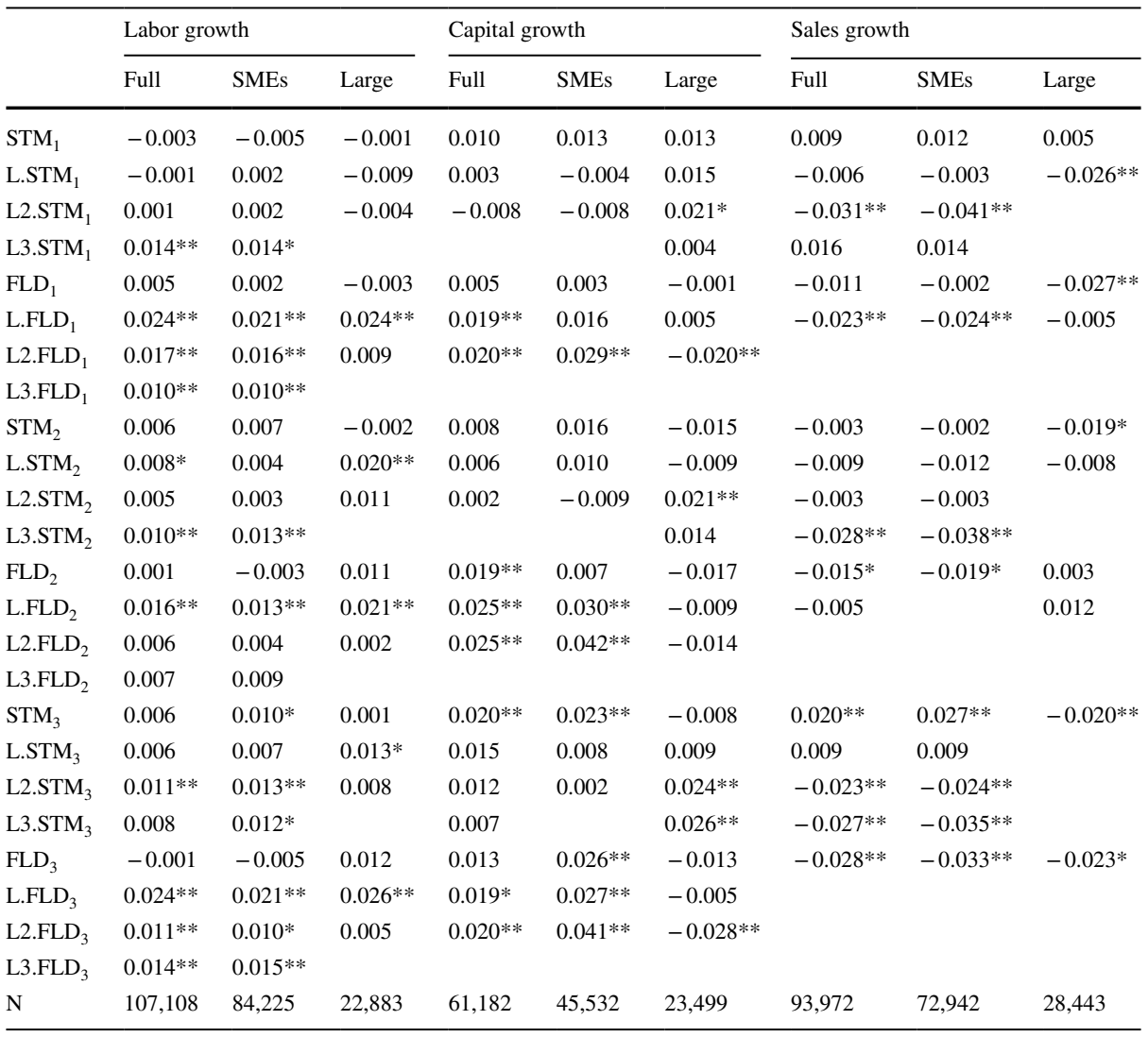

${ }^{*} p<0.10, * * p<0.05$. Estimation is done by system GMM. SMEs refer to firms with no more than 200 employees

capital growth in the same year and also in the following two years after their occurrence. Different from input growth, the combined net disaster impacts on sales growth are close to zero and insignificant except for the second lag ( -0.012 for $\mathrm{DIS}_{3}$ and -0.018 for $\left.\mathrm{DIS}_{1}\right)$. We no longer observe any large and significant disaster impacts on sales growth in the same year. The coefficients of the disaster dummies are also smaller than the coefficient estimates for storms and floods in Table 5 (in absolute terms).

\subsubsection{Varying the Cutoff Values for Defining Disaster Dummies}

Although the cutoff values used for defining the storm and flood dummies are mostly close to their respective sample medians, the choices remain arbitrary. Therefore, we perform additional robustness checks by varying the cutoff values for defining the disaster dummies. We present the estimation results with both higher and lower cutoff values for defining disaster events in Table 8. When we increase the cutoff values for defining storms and floods, we in fact look at the impacts of more severe disasters in terms of physical intensities, deaths, and estimated economic damage. The number of observations with natural 
Table 8 Disaster impact on firm growth: pooling storms and floods with varying cutoff values

\begin{tabular}{|c|c|c|c|c|c|c|c|c|c|}
\hline & \multicolumn{3}{|c|}{ Labor growth } & \multicolumn{3}{|c|}{ Capital growth } & \multicolumn{3}{|c|}{ Sales growth } \\
\hline & Baseline & High & Low & Baseline & High & Low & Baseline & High & Low \\
\hline $\mathrm{DIS}_{1}$ & -0.001 & 0.006 & 0.000 & 0.006 & $0.018 * *$ & 0.007 & 0.005 & 0.004 & -0.006 \\
\hline L.DIS 1 & $0.013 * *$ & $0.017 * *$ & 0.004 & $0.011 *$ & $0.034 * *$ & 0.003 & -0.010 & -0.006 & -0.006 \\
\hline $\mathrm{L}^{2 . D I S}{ }_{1}$ & $0.013 * *$ & $=0.022 * *$ & $0.011 * *$ & 0.011 & $0.014^{*}$ & $0.014 * *$ & $-0.018 * *$ & -0.012 & -0.008 \\
\hline L3.DIS $_{1}$ & $0.013 * *$ & $0.008 * *$ & $0.010 * *$ & & & & & & \\
\hline $\mathrm{DIS}_{2}$ & 0.003 & 0.005 & -0.004 & $0.023 * *$ & $0.014 *$ & $0.021 * *$ & -0.007 & -0.005 & 0.003 \\
\hline L.DIS ${ }_{2}$ & $0.013 * *$ & $0.018 * *$ & 0.004 & $0.023 * *$ & $0.025 * *$ & $0.024 * *$ & -0.003 & -0.002 & -0.006 \\
\hline${\mathrm{L} 2 . \mathrm{DIS}_{2}}_{2}$ & $0.008^{*}$ & $0.011 * *$ & $0.009 * *$ & $0.019 * *$ & $0.019 * *$ & $0.012 *$ & -0.009 & 0.001 & $-0.016^{* *}$ \\
\hline L3.DIS $_{2}$ & $0.015 * *$ & $0.010 * *$ & $0.016^{* *}$ & & & & & & \\
\hline $\mathrm{DIS}_{3}$ & 0.003 & 0.003 & 0.002 & $0.021 * *$ & $0.021 * *$ & $0.020 * *$ & 0.002 & 0.000 & 0.001 \\
\hline L.DIS ${ }_{3}$ & $0.016^{* *}$ & $0.018 * *$ & $0.015 * *$ & $0.021 * *$ & $0.019 * *$ & $0.021 * *$ & 0.006 & 0.005 & 0.004 \\
\hline${\mathrm{L} 2 . \mathrm{DIS}_{3}}_{3}$ & $0.012 * *$ & $=0.012 * *$ & $0.011 * *$ & $0.016^{* *}$ & $0.013^{*}$ & $0.014 * *$ & $-0.012^{*}$ & -0.008 & $-0.013^{* *}$ \\
\hline L3.DIS $_{3}$ & $0.013 * *$ & $=0.013 * *$ & $0.012 * *$ & & & & & & \\
\hline
\end{tabular}

${ }^{*} p<0.10, * * p<0.05$. The cutoff values for the storm (flood) dummies for baseline cases are respectively: 64,16 , and 25 (5, 45, and 10); the high cutoff values for the storm (flood) dummies are respectively: 83,30 , and $50(9,60$, and 30); the low cutoff values for the strom (flood) dummies are respectively: 56, 10, and 10 $(1,20$, and 5)

Table 9 Impacts of storms and floods on valued added growth

\begin{tabular}{llll}
\hline & $\mathrm{x}=1$ & $\mathrm{x}=2$ & $\mathrm{x}=3$ \\
\hline $\mathrm{STM}_{\mathrm{X}}$ & $-0.073^{* *}$ & $-0.024^{*}$ & $-0.026^{* *}$ \\
$\mathrm{L.STM}_{\mathrm{X}}$ & $-0.076^{* *}$ & $-0.026^{* *}$ & \\
$\mathrm{~L}^{*} . \mathrm{STM}_{\mathrm{X}}$ & $0.051^{* *}$ & & \\
L3.STM $_{\mathrm{X}}$ & $-0.073^{* *}$ & & \\
L4.STM $_{\mathrm{X}}$ & $-0.043^{* *}$ & & \\
$\mathrm{FLD}_{\mathrm{X}}$ & -0.005 & -0.029 & $-0.040^{* *}$ \\
L.FLD & -0.022 & 0.000 & -0.008 \\
L2.FLD & -0.015 & $-0.014^{* *}$ & $-0.055^{* *}$ \\
L3.FLD & -0.000 & $-0.074^{* *}$ & $-0.076^{* *}$ \\
L4.FLD & $-0.026^{* *}$ & & \\
N & 42,204 & 42,204 & 42,204 \\
ar2p & 0.208 & 0.262 & 0.216 \\
hansenp & 0.259 & 0.257 & 0.304 \\
Hansen_df & 32 & 32 & 32 \\
\hline
\end{tabular}

$* p<0.10, * * p<0.05, \mathrm{x}=1,2$, and 3 refer to physical intensities, deaths, and economic damage respectively. Value added gowth follows $\mathrm{AR}(5)$ process

disasters becomes smaller with higher cutoff values and vice versa with lower cutoff values. The coefficients and their significance change slightly but remain robust to the adjustment of the cutoff values for definining the disaster variables for all growth models. 


\subsubsection{Alternative Measure of Firm Growth: Value Added Growth}

Another commonly used measure of firm size in the firm growth literature is value added (VA hereafter) that reflects firm production, whereas sales not only reflect production but also idiosyncratic demand shocks. In the Enterprise Census data, value added is not directly reported but can be calculated as the sum of labor costs, profits, and depreciation. Hence VA is likely to suffer from measurement errors. Besides, the number of observations with non-missing VA is smaller than other size and growth measures. Hence sample selection bias could be larger with the VA growth measure than other growth measures. For these two reasons, we interpret the disaster impacts on value-added growth with caution.

Table 9 presents the estimation results. ${ }^{50}$ Similar to sales growth, almost all coefficients of the storm and flood dummies and their lags are negative. First, the impacts of storms on value added growth are mostly negative and significant, albeit with varying persistence across the three storm measures. The impacts of storms on value added growth last for four years with the physical intensity measure, but only one year with the economic damage measure. Second, floods also negatively impact value added growth, but this effect differs in scale and significance across the three flood measures. Only the coefficient for the fourth lag of the flood dummy is significant with the physical intensity measure. Flooding significantly reduces value added growth in the same year as well as two and three years later with both the number of deaths and the economic damage measures. Overall storms and floods have negative impacts on value added growth.

\subsection{The Economic Impact of Storms and Floods on Firm Growth}

The estimated coefficients for the storm and flood variables reported above show the causal impact of storms and floods on firm growth. To understand the disaster impacts more intuitively, we further convert the causal econometric results to (indirect) economic impacts (e.g., Elliott et al. 2015).

We first illustrate the conversion of the econometric results to economic impacts for labor growth in five steps. The conversion is similar for capital growth and sales growth. First, we sum the product of the (lagged) storm and flood variables with their corresponding (significant) coefficients. Second, we take the exponential transformation of the sum in the first step and minus one. Third, we multiply the value in the second step with the values of labor from the previous period for each firm. Fourth, we sum the values from step three across firms to arrive at the aggregate net changes in labor caused by storms and floods. Finally, we scale the aggregate net changes in employment by total employment from the previous year to arrive at the percentage change in total employment caused by storms and floods.

After conversion, we find that on average, storms and floods together increase the total employment by $0.25-0.43 \%$ and the total capital by $0.28-0.68 \%$, but decrease the aggregate sales by $0.24-0.30 \%$ per year for Vietnam manufacturing, depending on the disaster measures. The annual loss of aggregate sales by storms and floods varies across years ranging

\footnotetext{
50 Value added growth is negatively autocorrelated with its first 5 lags but the autocorrelation is only significant with its first lag. Similar to other growth measures, value added growth increases with firm size but decrease with firm age.
} 
from 1.1 MUSD in 2005 to 260 MUSD in 2008 with the economic damage measure. ${ }^{51,52}$ As a comparison, the largest direct economic damage recorded in EMDAT for Vietnam before 2015 is 640 MUSD (in 2013 dollar value) by typhoon Ketsana in 2009 whereas the estimated loss of aggregate sales is 170 MUSD in the same year with the economic damage measure. The total loss of aggregate sales during 2004-2014 ranges from 390 to 620 MUSD, depending on the disaster measures. This is smaller than the total annual net economic loss of 1 billion USD by typhoons for coastal China (Elliott et al. 2015), but not unreasonable because we focus on the sales in manufacturing while they studied the whole coastal economy in China.

\section{Conclusion}

In this paper we empirically identify the impacts of storms and floods on firm growth in labor, capital, and sales, using the Enterprise Census data (2000-2014) matched with three different disaster databases for Vietnam (EMDAT, GAME, and DFO). We assess and compare the growth impacts of different disaster measures that are defined based on physical intensities, number of deaths, and economic damage.

We find positive and significant impacts of flooding on labor growth and capital growth, and negative impacts on sales growth in the short run. The patterns for the impacts of storms on production factor growth are similar to the impacts of floods but with fewer significant coefficients. The positive (lagged) impacts on input growth could be due to postdisaster recovery and reconstruction. The impacts of storms on sales growth is mixed with some evidence of positive immediate impacts and negative lagged impacts, possibly due to the destruction of public infrastructure, supply chains, sales network, and negative demand shocks caused by storms and floods. Noticeably, the positive input growth doesn't lead to positive sales growth and output growth, similar to the findings in Leiter et al. (2009) for Europe. The argument of Leiter et al. (2009) may also be valid for Vietnam, namely that storms and floods may induce investment activities in production factors that go beyond the sole replacement of disaster losses and result in a less productive factor composition.

In this paper we make two methodological contributions to the literature. First, we pioneer in comparing the performance of different disaster measures that are defined based on physical intensities and socioeconomic losses (deaths and economic damages) at the firm level. We find that, the disaster impacts on firm growth are mostly consistent in signs and scales across the three disaster severity measures. This consistency is in contrast to the findings of aggregate disaster impacts at the macro level reported in Felbermayr and Gröschl (2014). Therefore both physical intensity and damage measures are reliable proxies for disaster severity and can be used to study the average disaster impacts across firms. Second, we estimate firm-level disaster impacts by the system GMM method, which accounts for endogeneity and measurement errors in variables. The estimation results are robust to the number of lagged values used as instruments. The successful application of

\footnotetext{
51 We converted the value of sales to US dollars using the World Bank 2013 exchange rate. The impact on aggregate sales in 2006 and 2013 is actually positive with the economic damage measure due to the significant positive coefficient for the economic damage measure for storms in the sales growth model.

52 The range of aggregate sales loss is similar with the physical intensity and number of deaths measures.
} 
the method can be extended to data from other countries to generate more insights into firm-level disaster impacts.

While we find that storms and floods on average have positive and significant impacts on labor growth and capital growth, more detailed analyses show a different picture for SMEs and large firms. The growth impacts of storms and floods are in general larger and last longer for SMEs than for large firms. It could be that SMEs are less capital intensive and experience lower physical damages and can adjust their input more quickly. But SMEs also experience larger negative impacts on sales growth, possibly due to the damage of public infrastructure and the disruption of supply chains.

For ease of understanding, we further convert the econometric results on firm growth to economic impacts. The increase in employment (capital) as a share of total employment (capital) is $0.25-0.43(0.28-0.68)$ percent, while the share of aggregate sales loss is $0.24-0.30 \%$ caused by storms and floods. The value of the aggregate sales loss in some years with severe storms and floods can be as large as 260 MUSD.

This paper is not without limitations. First, we examine the impacts on firm growth for storms and floods only. We are aware of the different nature of different disasters and do not seek to generalize the findings to all types of natural disasters. Second, due to data limitations, the disaster measures used in this paper cannot distinguish firms hit directly from firms not hit directly by natural disasters. The disaster dummies are defined at provincial levels, whereas disasters may impact areas smaller than a province. Nevertheless, with this approach we learn more about the aggregated net impacts of a disaster on firms in a province, including substitution effects experienced by firms that are not directly impacted. We suggest to extend the study to other countries with a broader variety of natural disasters to obtain a more complete picture of the firm level impacts by different types of natural disasters in the future. Moreover, future research can complement our study and provide more detailed insights into disaster impacts and mitigating factors by conducting a firm level survey that collects more detailed information on natural disaster impacts, such as whether firms are directly or indirectly hit by a natural disaster and the associated damages. Finally, natural disasters may have different impacts across sectors (e.g., agriculture, finance, tourism, et cetera), for which the empirical evidence remains thin. Therefore it is interesting to explore disaster impacts in these sectors for future research.

\section{Appendix 1: The Enterprise Census Data (2000-2014)}

The Enterprise Census was collected annually between March and May since 2000 by the General Statistical Office (GSO) of Vietnam. This data covers all state-owned and foreign enterprises, all private firms with employment above certain thresholds, and a random sample of private firms with employment below the thresholds, from all economic sectors in Vietnam. The size thresholds and sampling frame vary both across provinces/cities and over time. The size thresholds and sampling frames in Hanoi, Ho Chi Minh City, Hai Phong, Dong Nai, and Binh Duong are different from other provinces. Some provinces (e.g., Lai Chau, Ha Giang, Dien Bien, and Bac Kan) have small numbers of enterprises and hence all enterprises in these provinces are included in the survey (No. 1A-DTDN). Random sampling is applied to private firms with employment below the thresholds (No. 
1B-DTDN). Questionnaire 1B-DTDN asks less information on firms than questionnaire No. 1A-DTDN. GSO imputed the missing data but it is unclear how they did it. ${ }^{53}$

\section{Panel Data Construction}

In this paper, we only use the dataset with the name of dn*.dta $(*$ refers to year of data collection, namely from 2000 to 2014) collected based on questionnaire 1A_DTDN. Since the province codes (variable "tinh") for 2000-2003 and 2004 onwards are different, we first convert the province codes for 2000-2003 to the province codes for 2004. Similarly, the industrial classification codes used in 2000-2005 (VSIC1993) are different from the industrial classification codes used in 2006-2015 (VSIC2007). We use the concordance table to match and convert the two different industrial classification codes. We then pool the data across years.

To construct a panel dataset for use, we need panel identifiers for firms, which are not available for all years in our version of the Census data. Specifically, there are two different panel identifiers ("madn" and "ma_thue") available in some years. The panel identifier "madn" is available for 2000-2008 and 2013. The panel identifier "ma_thue" is available for 2000-2004, 2010-2012 and 2014-2015. We first assume that incumbent firms do not reallocate to other provinces. We then use "madn", the combination of "tinh macs" (province code and firm number), ${ }^{54}$ the changes of total assets between the beginning of this year and end of last year and other firm level information (e.g., enterprise types, 4-digit industry codes, et cetera) to recover missing "ma_thue". After recovery, the combination "ma_thue tinh macs" uniquely identifies each firm in the data and hence serves as the panel identifier.

\section{Data Cleaning}

For analysis, we first clean the constructed panel data. Specifically, we drop: (1) firms in tobacco, coke and refined petroleum, and recycling industries with small numbers of firms (most of them are state-owned), (2) all observations with duplicates in terms of identity numbers, province code, enterprise code, and (beginning and end of year) total assets, (3) extra duplicates in key variables including sales, total assets, employment, labor compensation, 4-digit industry codes, and enterprise types within the same province but with different panel identifiers (if available), (4) firms with constant values in total and fixed assets, sales, labor, and labor costs over time, (5) firms with missing or non-positive values in firm identifiers, ownership, sales, total and fixed assets, labor, and labor costs, and (6) firms with extreme growth in sales and capital. Growth rate is defined as the log difference in firm size in two consecutive years. ${ }^{55}$ The outliers are defined with the growth rates above the user-defined upper bounds ( 50 for total assets, 100 for fixed assets and long

\footnotetext{
53 We find many duplicates in terms of province, 4-digit industry code, sales, labor, and total assets, especially in Hanoi and Ho Chi Minh city, but with different panel identifiers (if available) and firm identity numbers ("macs").

54 Note that "macs" (firm number) doesn't change for the same firm since 2004 but vary every year before 2004.

55 In case of first time appearance in the data, the growth is defined by the ratio of the end of period values over the beginning of period values in the same year. The recall bias can be large for beginning of period values with a recall length of at least 15 months.
} 
term investment and labor, and 200 for sales) or below the lower bounds (0.02 for total capital, 0.01 for fixed capital, labor, and labor costs, and 0.005 for sales). ${ }^{56}$ We also drop the outliers only if they also satisfy one of the following conditions: (1) firms only appear 2 consecutive years in the panel, (2) for each firm, there is only one outlier defined by each variable and this outlier either occurs in its first or last year in the data. The cleaning above leaves out about $14.5 \%$ of the firm-year observations.

Furthermore, the top and bottom $1 \%$ of the data for the key variables are trimmed, including sales/capital/labor growth, investment rate, cash flow asset ratio, liquid assets and short-term investment to total assets, and liability to total asset. Also, all firms with gaps in years are dropped.

For estimating the growth models, we focus on firms with at least 5 years of observations. All nominal values are deflated by 2-digit industry deflators with 1994 as the base year. Table 10 shows the definitions of key variables for use from the Enterprise Census data.

\section{Appendix 2: Three Disaster Databases}

In this appendix, we introduce three different disaster databases for use in the paper.

\section{The ifo Geological and Meteorological Events Database (GAME)}

The ifo Geological and Meteorological Events (GAME) database is a country-level database covering a rich collection of variables for all countries worldwide from 1979 to 2014. The dataset collects information on geological and meteorological events including earthquakes, volcanic eruptions, storms, extreme temperature events, floods, and droughts from primary information. GAME provides a unique dataset for economic analysis as the disaster measures feature variation that is presumably exogenous to economic outcomes. We use the primary information for the two most frequent and disruptive disaster events, namely tropical storms (typhoons) and floods, from Vietnam to construct disaster measures for analysis. We measure the severity of typhoons by wind speed.

\section{Wind Speed Data}

GAME uses two primary data sources for storms (typhoons or hurricanes): the International Best Track Archive for Climate Stewardship (IBTrACS) and the Global Surface Summary of Day (GSOD) data. The IBTrACS data (version v03r03) ${ }^{57}$ records data of individual hurricane events, positions (latitude and longitude) of hurricane centers at 6-hourly intervals, combined with intensity information (wind speed in knots and barometric pressure). The raw 'best track' data give no indication on affected countries. GAME use geographic information system (GIS) software to map hurricane position data to affected

\footnotetext{
56 These cutoff values are slightly larger (smaller) than the corresponding 99th (1st) percentiles.

57 The IBTrACS data is provided by the National Climatic Data Center of the National Oceanic and Atmospheric Administration (NOAA). The data incorporate information from a variety of sources, such as reconnaissance aircraft, ships and satellites.
} 
Table 10 Variable definitions. Source: The enterprise census data (2000-2014)

\begin{tabular}{ll}
\hline $\ln L$ & Log of total employment \\
\hline $\ln K$ & Log of end of period fixed assets and long term investment \\
$\ln S$ & Log of total sales \\
growthL & Relative labor growth, $=\log \left(\mathrm{L}_{\mathrm{t}} / \mathrm{L}_{\mathrm{t}-1}\right)$ \\
growthK & Relative capital growth, $=\log \left(\mathrm{K}_{\mathrm{t}} / \mathrm{K}_{\mathrm{t}-1}\right)$ \\
growthS & Relative sales growth, $=\log \left(\mathrm{S}_{\mathrm{t}} / \mathrm{S}_{\mathrm{t}-1}\right)$ \\
IKx & Net change of fixed assets and long term investment in a year plus deprecia- \\
& tion, scaled by end of previous period fixed assets and long term investment \\
DAR & End of period accumulated debts scaled by end of previous period total assets \\
CFK & Cash flow scaled by the end of previous period total assets \\
CKK & End of year liquid assets and short-term investment, scaled by the end of \\
& previous period total assets \\
lnmwage & Log of mean wage per worker \\
femalep & The share of female workers in total employment
\end{tabular}

${ }^{a}$ In the finance literature DAR is typically defined as total long-term debt to asset ratio but it is not possible to distinguish between long-term and short-term debts in our data. However, there is plenty of anecdotal evidence that most private firms in Vietnam have short-term debts but hardly any long-term debts

countries. They consider positions (latitude and longitude) on land and positions off the coastline of a country.

To capture tornadoes and winter and summer storms (not captured by the IBTrACS data), the hurricane track data is matched to daily data of the GSOD data (version 7) on maximum wind speed and wind gust. ${ }^{58}$ GSOD uses daily summaries of hourly observations contained in the Integrated Surface Data (ISD). They collapse daily extremes on wind speed and wind gust over all stations on a country basis. Combining both datasets, we obtain a measure that brings together wind speed from the hurricane track data and wind speed from GSOD.

The variable "hurrfield" records the maximum hurricane wind speed data in knots. We convert the monthly data from per grid cell $(50 \mathrm{~km}$ by $50 \mathrm{~km})$ to per province basis. Since hurricanes may occur multiple times in a month and in a year, we construct the data for hurricanes on a yearly basis by selecting the observations with maximum wind speed. We also record the hurricane frequency if the maximum wind speeds exceed the threshold of 64 knots multiple times in a year. ${ }^{59}$ After conversion, we have 326 observations with nonmissing data for "hurrfield" and only 69 observations with the maximum hurricane wind speed equal or exceeding 64 knots. $^{60}$

The conversion from per grid cell to per province has a few concerns. Note that the same windstorm can be recorded in multiple grid cells, a province often consists of multiple grid cells, and some grid cells may be located on the borders of multiple provinces. It is likely that the share of area in a province hit by a storm with high wind speed is small.

\footnotetext{
58 This dataset includes records of wind speed from over 9000 worldwide stations and is produced by the National Climatic Data Center (NCDC).

59 The Saffir-Simpson Hurricane Wind Scale is a 1 (64-82 knots) to 5 (136+knots) rating based on a hurricane's sustained wind speed.

60 After conversion there are 12 observations per year per province (total 63 provinces) between 2000 and 2014 . Hence there are in total 11,340 observations in the 15-year period.
} 
Table 11 Distribution of wind speed in knots

\begin{tabular}{lclc}
\hline Percentiles & Hurrfield & $\begin{array}{l}\text { Hurrfield } \\
(\geq 64 \mathrm{kt})\end{array}$ & $\begin{array}{l}\text { Hurrfield_ } \\
\text { weighted }\end{array}$ \\
\hline $1 \%$ & 34 & 64 & 64 \\
$25 \%$ & 40 & 67 & 68 \\
$50 \%$ & 48 & 71 & 73 \\
$75 \%$ & 60 & 78 & 78 \\
$99 \%$ & 92 & 99 & 101 \\
Obs. (2000-2014) & 326 & 69 & 58 \\
\hline
\end{tabular}

Therefore, the final wind speed for a province can be calculated as the weighted average of the wind speed for multiple cells, with the weights equal to the ratio of the grid cell size over the size of the province in which the cell is located. ${ }^{61}$ But the potential downward bias is large if some part of the province has low wind speed, resulting in too few severe hurricanes. We take an alternative strategy of calculating the weighted average of wind speed equal to or above the threshold of 64 knots for the grid cells in a province with their relative sizes in a province above $10 \%$. Table 11 presents the distribution of raw and weighted wind speed data.

\section{Precipitation Data}

Precipitation data are recorded by the Goddard Space Flight Center of the National Aeronautics and Space Administration (NASA) in the Global Precipitation Climatology Project (GPCP). The GPCP combines weather station rainfall gauge measures and satellite information. Total monthly precipitation data are provided in millimeters $(\mathrm{mm})$ for 2.5 latitude and longitude degree grid nodes. The data is brought to the country level by matching rainfall estimates per node to the corresponding country using GIS software and they average rainfall across nodes to produce an estimate of total monthly rainfall per country (Miguel et al. 2004; Brückner and Ciccone 2011). If no degree node fell within the national boundaries of a country, they assigned the rainfall measures from the nearest node(s) to their borders. The principal measure of weather variation is the difference in monthly rainfall in $\mathrm{mm}$, which is defined as the proportional (positive) deviation of total monthly rainfall from average monthly rainfall for the entire available time period (1979-2010). ${ }^{62}$ Some grid cells may be located on the border of two or more provinces and some provinces may consist of multiple grid cells with different values. We match the grid cells to corresponding provinces using GIS software. Similar to hurricane wind speed data, the precipitation data also need to be converted into one observation per year per province similar to the conversion of wind speed data.

The precipitation data can be a poor proxy for floods. Whether heavy precipitation will cause floods or not depends on the intensity and duration of rainfall, the geographical landscape (degree of urbanization, vegetation, soil saturation, steepness, et cetera), and other

\footnotetext{
61 The grid cell may be partialy or fully located in a province.

62 They create an indicator for droughts, which takes the value of unity if at least three subsequent months have rainfall below $50 \%$ of the long-run average monthly mean, or if at least five months within a year have rainfall below 50 percent of the long-run monthly mean, and zero otherwise. A single dry month often does not cause a drought.
} 
Table 12 Major natural disaster events (1990-2019). Source: www.emdat.be/database

\begin{tabular}{llrrrr}
\hline Disaster type & Disaster subtype & Events count & Total deaths & Total affected & $\begin{array}{l}\text { Total damage } \\
\text { ('000 US\$) }\end{array}$ \\
\hline Drought & Drought & 5 & 0 & $7,860,000$ & $7,399,120$ \\
Flood & - & 12 & 248 & $1,141,287$ & 160,055 \\
Flood & Coastal flood & 6 & 804 & $4,353,316$ & 749,000 \\
Flood & Flash flood & 14 & 495 & $1,034,317$ & 541,700 \\
Flood & Riverine flood & 48 & 3281 & $18,562,256$ & $2,886,407$ \\
Landslide & Avalanche & 1 & 200 & 38,000 & 0 \\
Landslide & Landslide & 4 & 109 & 40 & 0 \\
Landslide & Mudslide & 1 & 21 & 1034 & 2300 \\
Storm & - & 9 & 301 & 219,280 & 145,035 \\
Storm & Convective storm & 7 & 64 & 4513 & 10,100 \\
Storm & Tropical cyclone & 71 & $21,968,626$ & $9,913,857$ \\
\hline
\end{tabular}

Table 13 Distribution of storms and floods from the three disaster datasets (2000-2014)

\begin{tabular}{|c|c|c|c|c|}
\hline & \multicolumn{2}{|l|}{ Storms } & \multicolumn{2}{|l|}{ Floods } \\
\hline & Game & Emdat & Emdat & DFO \\
\hline 2000 & 3 & 4 & 2 & 6 \\
\hline 2001 & 17 & 3 & 3 & 6 \\
\hline 2002 & 0 & 1 & 3 & 10 \\
\hline 2003 & 12 & 0 & 3 & 8 \\
\hline 2004 & 9 & 2 & 3 & 4 \\
\hline 2005 & 13 & 4 & 5 & 9 \\
\hline 2006 & 14 & 6 & 5 & 6 \\
\hline 2007 & 11 & 1 & 5 & 7 \\
\hline 2008 & 4 & 5 & 5 & 7 \\
\hline 2009 & 10 & 3 & 2 & 4 \\
\hline 2010 & 2 & 3 & 4 & 5 \\
\hline 2011 & 0 & 1 & 3 & 1 \\
\hline 2012 & 20 & 3 & 1 & 2 \\
\hline 2013 & 29 & 4 & 6 & 1 \\
\hline 2014 & 21 & 2 & 0 & 1 \\
\hline Total & $165^{\mathrm{a}}$ & 42 & 49 & 77 \\
\hline
\end{tabular}

Note that we exclude storms and floods with both zero death and zero damages and also observations with wind speed above 64 knots but with grid cell smaller than $15 \mathrm{~km}^{2}$

${ }^{a}$ Based on the year and month occurred, there are around 22 storms with wind speed above 63 knots. There are 256 observations if we lower the cutoff value from 64 to 56 knots

factors. It is also likely that extreme precipitation occurs in one region, but causes floods in other regions. 


\section{Data Matching and Comparison}

Apart from GAME, we also use two other disaster databases, the Emergency Event Database (EM-DAT) ${ }^{63}$ and the Dartmouth Flood Observatory (DFO), a Global Active Archive of Large Flood Events since 1985. ${ }^{64}$

Table 12 list the major natural disaster events in Vietnam for the period of 1990-2019 from the EM-DAT database. Storms and floods are the most frequent and severe natural disaster events in Vietnam.

We then merge the three disaster databases for storms and floods. Table 13 below lists the distribution of storms and floods across years from the three disaster datasets. The three disaster datasets only partially identify the common storms and floods. Although data in GAME is not directly comparable with EM-DAT, we spot some inconsistency in the disaster events recorded in the two datasets. For example, there are 12 observations in GAME with wind speed of 64 knots or higher but no storms in 2003 according to EM-DAT. While EM-DAT records one storm in 2002 and 2011 respectively, there are no observations with wind speed of 64 knots or higher in GAME. ${ }^{65}$ Also, DFO records more flood events than EM-DAT.

\section{Appendix 3: Maps of Vietnam}

See Figs. 1, 2 and 3.

${ }^{63}$ EM-DAT is collected by the center for research on the epidemiology of disasters (CRED), Université catholique de Louvain, Brussels, Belguim.

64 G.R.Brakenridge, "Global Active Archive of Large Flood Events", Dartmouth Flood Observatory, University of Colorado, http://floodobservatory.colorado.edu/Archives/index.html.

65 This difference is in part related to the threshold chosen (64 knots). The number increases from zero to four if we lower the threshold to 56 knots for 2011 but not for 2002. 


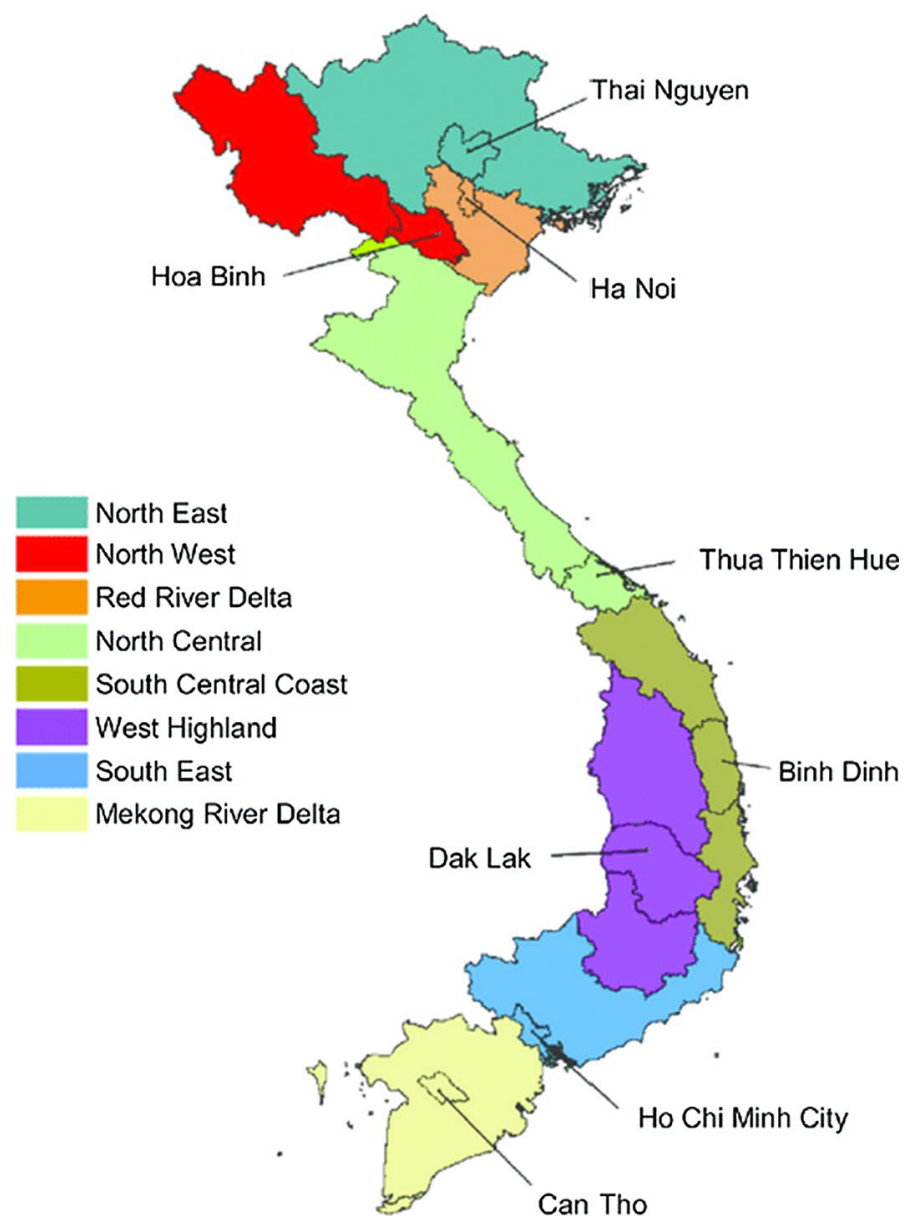

Fig. 1 Vietnam by regions. Source: Bui et al. (2016) 


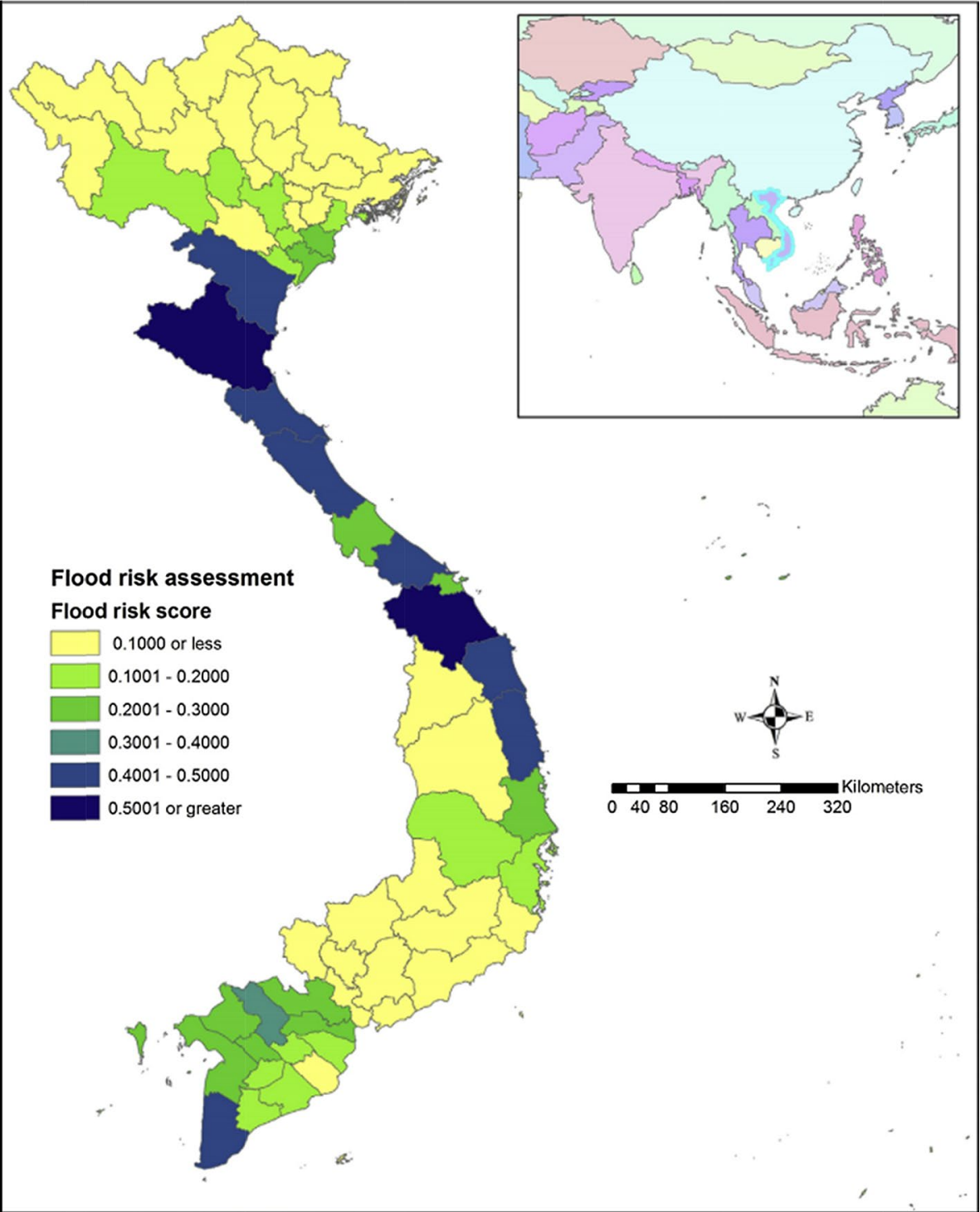

Fig. 2 Spatial patterns of flood risk assessment by provinces in Vietnam. Source: Luu et al. (2019) 


\section{Vietnam's Four Key Economic Zones}

Provinces, Total Land Areas, and Populations

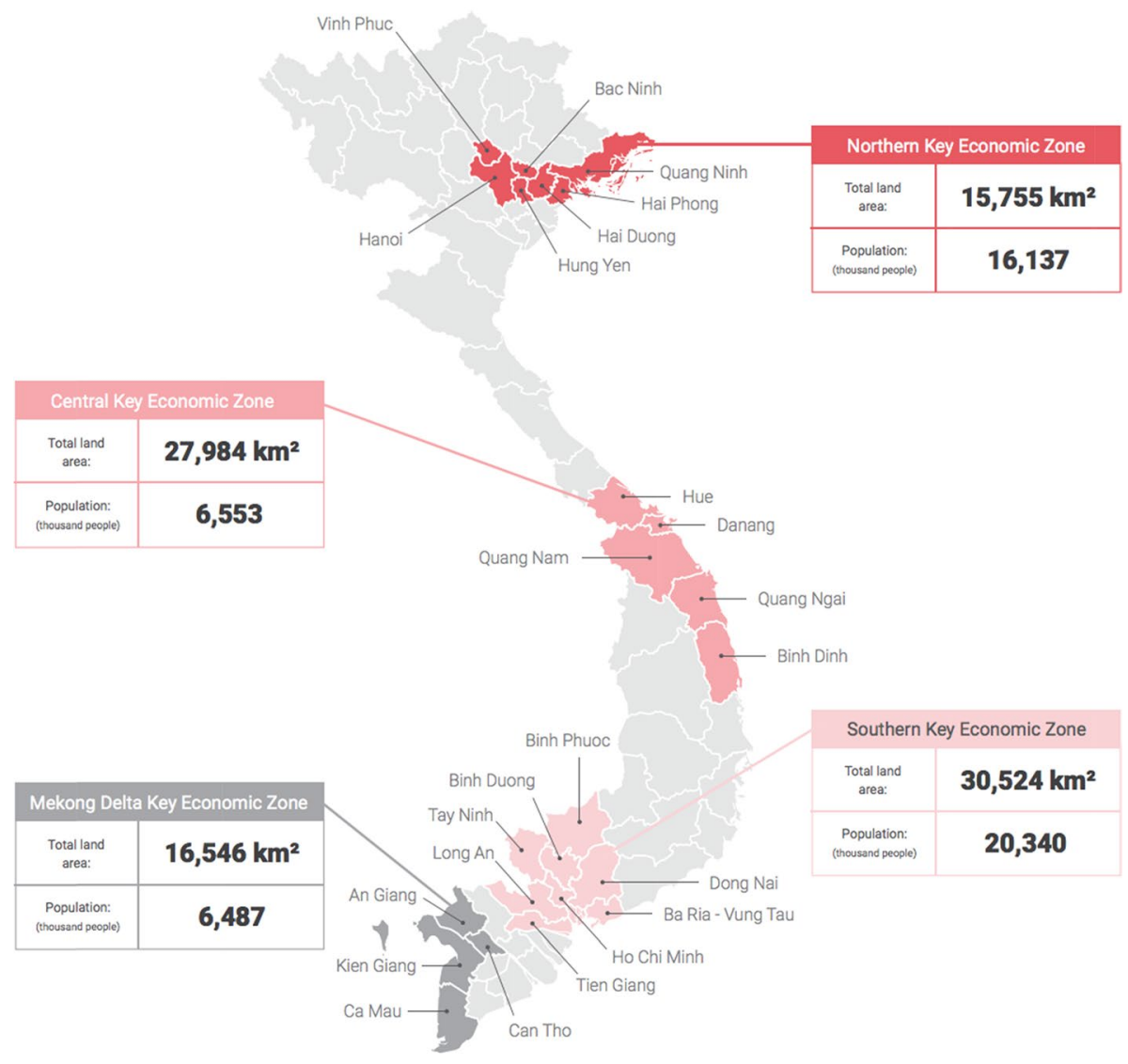

Source: Government Portal, Overview About the Key Economic Zones

Fig. 3 Vietnam's four key economic zones. Source: Asia Perspective (2019) 


\section{Appendix 4: Sales Growth Across 3 Groups of Firms with Different Capital Intensities}

See Table 14.

Table 14 Sales growth across firms with low, medium, and high capital intensities

\begin{tabular}{lllll}
\hline & Full sample & Labor intensive & $\begin{array}{l}\text { Medium capital } \\
\text { intensity }\end{array}$ & Capital intensive \\
\hline STM3 & $0.020^{* *}$ & $0.037^{* *}$ & 0.003 & -0.007 \\
L.STM3 & 0.009 & $0.021^{*}$ & -0.000 & -0.009 \\
L2.STM3 & $-0.022^{* *}$ & & $-0.045^{* *}$ & 0.014 \\
L3.STM3 & $-0.027^{* *}$ & & $-0.033^{* *}$ & \\
FLD3 & $-0.029^{* *}$ & $-0.038^{* *}$ & $-0.031^{*}$ & $0.034^{* *}$ \\
N & 93,972 & 38,631 & 33,440 & 27,365 \\
ar2p & 0.489 & 0.143 & 0.456 & 0.232 \\
hansenp & 0.205 & 0.438 & 0.500 & 0.242 \\
hansen_df & 76 & 76 & 76 & 73 \\
\hline
\end{tabular}

Open Access This article is licensed under a Creative Commons Attribution 4.0 International License, which permits use, sharing, adaptation, distribution and reproduction in any medium or format, as long as you give appropriate credit to the original author(s) and the source, provide a link to the Creative Commons licence, and indicate if changes were made. The images or other third party material in this article are included in the article's Creative Commons licence, unless indicated otherwise in a credit line to the material. If material is not included in the article's Creative Commons licence and your intended use is not permitted by statutory regulation or exceeds the permitted use, you will need to obtain permission directly from the copyright holder. To view a copy of this licence, visit http://creativecommons.org/licenses/by/4.0/.

\section{References}

Abadie A, Athey S, Imbens GW, Wooldridge J (2017) When should you adjust standard errors for clustering? No. w24003. National Bureau of Economic Research. https://doi.org/10.3386/w24003

Altay N, Ramirez A (2010) Impact of disasters on firms in different sectors: implications for supply chains. J Supply Chain Manag 46(4):59-80. https://doi.org/10.1111/j.1745-493X.2010.03206.x

Anbarci N, Escaleras M, Register C (2005) Earthquake fatalities: the interaction of nature and political economy. J Public Econ 89(9-10):1907-1933

Asia Perspective (2019) Vietnam key economic zones \& investment guideline. Asia Perspective. http://asiap erspective.net/ap17/wp-content/uploads/2019/11/ap-vietnam-kez-report-part-one-251119a.pdf

Ayyagari M, Demirgüç-Kunt A, Maksimovic V (2008) How important are financing constraints? The role of finance in the business environment. World Bank Econ Rev 22(3):483-516. https://doi.org/10.1093/ wber/lhn018

Baez J, de la Fuente A, Santos I (2010) Do natural disasters affect human capital? An assessment based on existing empirical evidence. IZA discussion paper no. 5164. https://econpapers.repec.org/paper/izaiz adps/dp5164.htm

Banerjee L (2007) Effect of flood on agricultural wages in Bangladesh: an empirical analysis. World Dev 35(11):1989-2009. https://doi.org/10.1016/j.worlddev.2006.11.010

Belasen AR, Polachek SW (2008) How hurricanes affect wages and employment in local labor markets. Am Econ Rev 98(2):49-53. https://doi.org/10.1257/aer.98.2.49

Belasen AR, Polachek SW (2009) How disasters affect local labor markets: the effects of hurricanes in Florida. J Hum Resour 44(1):251-276 
Bentzen J, Madsen ES, Smith V (2012) Do firms' growth rates depend on firm size? Small Bus Econ 39(4):937-947. https://doi.org/10.1007/s11187-011-9341-8

Bertinelli L, Strobl E (2013) Quantifying the local economic growth impact of hurricane strikes: an analysis from outer space for the caribbean. J Appl Meteorol Climatol 52(8):1688-1697

Blaikie P, Cannon T, Davis I, Wisner B, Cannon T, Davis I, Wisner B (2014) At risk: natural hazards, people's vulnerability and disasters. Routledge, London . https://doi.org/10.4324/9780203714775

Blundell R, Bond S (1998) Initial conditions and moment restrictions in dynamic panel data models. J Econ 87(1):115-143. https://doi.org/10.1016/S0304-4076(98)00009-8

Bottazzi G, Secchi A (2003) Common properties and sectoral specificities in the dynamics of US manufacturing companies. Rev Ind Organ 23(3/4):217-232. https://doi.org/10.1023/B:REIO.0000031366.28559.c1

Bottazzi G, Secchi A, Tamagni F (2006) Financial fragility and growth dynamics of Italian business firms. LEM papers series 2006/07. https://ideas.repec.org/p/ssa/lemwps/2006-07.html

Bottazzi G, Coad A, Jacoby N, Secchi A (2011) Corporate growth and industrial dynamics: evidence from French manufacturing. Appl Econ 43(1):103-116

Botzen WJW, Deschenes O, Sanders M (2019) The economic impacts of natural disasters: a review of models and empirical studies. Rev Environ Econ Policy 13(2):167-188. https://doi.org/10.1093/reep/rez004

Bouwer LM (2019) Observed and projected impacts from extreme weather events: implications for loss and damage. In: Mechler R, Bouwer LM, Schinko T, Surminski S, Linnerooth-Bayer J (eds) Loss and damage from climate change: concepts, methods and policy options. Springer, Berlin, pp 63-82. https://doi. org/10.1007/978-3-319-72026-5_3

Brückner M, Ciccone A (2011) Rain and the democratic window of opportunity. Econometrica 79(3):923-947

Bui TV, Blizzard CL, Luong KN, Truong NLV, Tran BQ, Otahal P, Gall S, Nelson MR, Au TB, Ha ST, Phung HN, Tran MH, Callisaya M, Srikanth V (2016) National survey of risk factors for non-communicable disease in Vietnam: prevalence estimates and an assessment of their validity. BMC Public Health 16(1):498. https://doi.org/10.1186/s12889-016-3160-4

Cabral L (1995) Sunk costs, firm size and firm growth. J Ind Econ 43(2):161-172

Carvalho VM, Nirei M, Saito YU, Tahbaz-Salehi A (2016) Supply chain disruptions: evidence from the great east Japan earthquake. Discussion papers no. 287. Policy Research Institute, Ministry of Finance Japan. https://ideas.repec.org/p/mof/wpaper/ron287.html

Cavallo E, Noy I (2011) Natural disasters and the economy-a survey. Int Rev Environ Resour Econ 5(1):63102. https://doi.org/10.1561/101.00000039

Cavallo E, Galiani S, Noy I, Pantano J (2013) Catastrophic natural disasters and economic growth. Rev Econ Stat 95(5):1549-1561. https://doi.org/10.1162/REST_a_00413

Coad A (2007a) Firm growth: a survey. Documents de travail du Centre d'Economie de la Sorbonne r07024, Université Panthéon-Sorbonne (Paris 1), Centre d'Economie de la Sorbonne. https://ideas.repec.org/p/ $\mathrm{mse} / \mathrm{cesdoc} / \mathrm{r} 07024 . \mathrm{html}$

Coad A (2007b) A closer look at serial growth rate correlation. Rev Ind Organ 31(1):69-82. https://doi.org/ $10.1007 / \mathrm{s} 11151-007-9135-\mathrm{y}$

Coad A (2009) The growth of firms. In: Books. Edward Elgar Publishing. https://ideas.repec.org/b/elg/ eebook/13424.html

Cole MA, Elliott RJR, Toshihiro O, Strobl E (2015) Natural disasters, industrial clusters and manufacturing plant survival. RIETI discussion paper series 15-E-008, p 36

Cuaresma JC (2010) Natural disasters and human capital accumulation. World Bank Econ Rev 24(2):280-302

De Mel S, McKenzie D, Woodruff C (2012) Enterprise recovery following natural disasters. Econ J 122(559):64-91. https://doi.org/10.1111/j.1468-0297.2011.02475.x

Del Valle A, Elliott RJR, Strobl E, Tong M (2018) The short-term economic impact of tropical cyclones: satellite evidence from Guangdong province. Econ Dis Climate Change 2(3):225-235. https://doi.org/ $10.1007 / \mathrm{s} 41885-018-0028-3$

Delmar F (2006) Measuring growth: methodological considerations and empirical results. In: Davidsson P, Delmar F, Wiklund J (eds) Entrepreneurship and the growth of firms. Edward Elgar Publishing, London

Denis DJ, Sibilkov V (2010) Financial constraints, investment, and the value of cash holdings. Rev Financ Stud 23(1):247-269. https://doi.org/10.1093/rfs/hhp031

Elliott RJR, Strobl E, Sun P (2015) The local impact of typhoons on economic activity in China: a view from outer space. J Urban Econ 88:50-66. https://doi.org/10.1016/j.jue.2015.05.001

EM-DAT (2020) EMDAT: the emergency events database-Université catholique de Louvain (UCL)CRED,D. Guha-Sapir. www.emdat.be, Brussels, Belgium

Estrada F, Botzen WJW, Tol RSJ (2015) Economic losses from US hurricanes consistent with an influence from climate change. Nat Geosci 8(11):880-884. https://doi.org/10.1038/ngeo2560 
Evans DS (1987) The relationship between firm growth, size, and age: estimates for 100 manufacturing industries. J Ind Econ 35(4):567-581. https://doi.org/10.2307/2098588

Ewing BT, Kruse JB, Thompson MA (2003) A comparison of employment growth and stability before and after the Fort Worth tornado. Glob Environ Change Part B Environ Hazards 5(3):83-91. https:// doi.org/10.1016/j.hazards.2004.05.002

Ewing BT, Kruse JB, Thompson MA (2009) Twister! employment responses to the 3 May 1999 Oklahoma City tornado. Appl Econ 41(6):691-702. https://doi.org/10.1080/00036840601007468

Farre-Mensa J, Ljungqvist A (2016) Do measures of financial constraints measure financial constraints? Rev Financ Stud 29(2):271-308. https://doi.org/10.1093/rfs/hhv052

Felbermayr G, Gröschl J (2014) Naturally negative: the growth effects of natural disasters. J Dev Econ 111:92-106. https://doi.org/10.1016/j.jdeveco.2014.07.004

GFDRR (2015) Country profile: Vietnam. https://www.gfdrr.org/en/publication/country-profile-vietnam

Hall BH (1987) The relationship between firm size and firm growth in the US manufacturing sector. J Ind Econ 35(4):583-606. https://doi.org/10.2307/2098589

Hallegatte S, Przyluski V (2010) The economics of natural disasters: concepts and methods. World Bank. https://doi.org/10.1596/1813-9450-5507

Head K, Ries J, Swenson D (1995) Agglomeration benefits and location choice: evidence from Japanese manufacturing investments in the United States. J Int Econ 38(3):223-247. https://doi.org/10.1016/ 0022-1996(94)01351-R

Hosono K, Miyakawa D, Uchino T, Hazama M, Ono A, Uchida H, Uesugi I (2016) Natural disasters, damage to banks, and firm investment: natural disaster and firm investment. Int Econ Rev 57(4):13351370. https://doi.org/10.1111/iere.12200

Hyytinen A, Toivanen O (2005) Do financial constraints hold back innovation and growth? Res Policy 34(9):1385-1403. https://doi.org/10.1016/j.respol.2005.06.004

IPCC (2014) Climate change 2014-impacts, adaptation and vulnerability: part A: global and sectoral aspects: working group II contribution to the IPCC 5th assessment report: volume 1: global and sectoral aspects, vol 1. Cambridge University Press, Cambridge. https://doi.org/10.1017/CBO9781107 415379

Kahn ME (2005) The death toll from natural disasters: the role of income, geography, and institutions. Rev Econ Stat 87(2):271-284

Kirchberger M (2017) Natural disasters and labor markets. J Dev Econ 125:40-58. https://doi.org/10. 1016/j.jdeveco.2016.11.002

Klomp J (2014) Financial fragility and natural disasters: an empirical analysis. J Financ Stab 13:180-192. https://doi.org/10.1016/j.jfs.2014.06.001

Klomp J, Valckx K (2014) Natural disasters and economic growth: a meta-analysis. Glob Environ Chang 26:183-195. https://doi.org/10.1016/j.gloenvcha.2014.02.006

Koks EE, Bočkarjova M, de Moel H, Aerts JCJH (2015) Integrated direct and indirect flood risk modeling: development and sensitivity analysis. Risk Anal 35(5):882-900. https://doi.org/10.1111/risa. 12300

Kucera D, Sarna R (2006) Trade union rights, democracy, and exports: a gravity model approach. Rev Int Econ 14(5):859-882. https://doi.org/10.1111/j.1467-9396.2006.00627.x

Lazzaroni S, van Bergeijk PAG (2014) Natural disasters' impact, factors of resilience and development: a meta-analysis of the macroeconomic literature. Ecol Econ 107:333-346. https://doi.org/10.1016/j. ecolecon.2014.08.015

Leiter AM, Oberhofer H, Raschky PA (2009) Creative disasters? Flooding effects on capital, labour and productivity within European firms. Environ Resour Econ 43(3):333-350. https://doi.org/10.1007/ s10640-009-9273-9

Linnenluecke MK, Stathakis A, Griffiths A (2011) Firm relocation as adaptive response to climate change and weather extremes. Glob Environ Chang 21(1):123-133. https://doi.org/10.1016/j.gloenvcha. 2010.09.010

Loayza NV, Olaberría E, Rigolini J, Christiaensen L (2012) Natural disasters and growth: going beyond the averages. World Dev 40(7):1317-1336. https://doi.org/10.1016/j.worlddev.2012.03.002

Luu C, von Meding J, Mojtahedi M (2019) Analyzing Vietnam's national disaster loss database for flood risk assessment using multiple linear regression-TOPSIS. Int J Dis Risk Reduct 40:101153. https:// doi.org/10.1016/j.ijdrr.2019.101153

McDermott TKJ (2012) The effects of natural disasters on human capital accumulation (SSRN scholarly paper ID 2011768). Soc Sci Res Netw. https://doi.org/10.2139/ssrn.2011768

Meyer KE, Nguyen HV (2005) Foreign investment strategies and sub-national institutions in emerging markets: evidence from Vietnam. J Manag Stud 42(1):63-93. https://doi.org/10.1111/j.1467-6486. 2005.00489.x 
Miao Q, Popp D (2014) Necessity as the mother of invention: innovative responses to natural disasters. J Environ Econ Manag 68(2):280-295. https://doi.org/10.1016/j.jeem.2014.06.003

Miguel E, Satyanath S, Sergenti E (2004) Economic shocks and civil conflict: an instrumental variables approach. J Polit Econ 112(4):725-753. https://doi.org/10.1086/421174

Mohan P, Strobl E (2017) The short-term economic impact of tropical cyclone pam: an analysis using VIIRS nightlight satellite imagery. Int J Remote Sens 38(21):5992-6006. https://doi.org/10.1080/ 01431161.2017.1323288

Musso P, Schiavo S (2008) The impact of financial constraints on firm survival and growth. J Evol Econ 18(2):135-149. https://doi.org/10.1007/s00191-007-0087-z

Noy I (2009) The macroeconomic consequences of disasters. J Dev Econ 88(2):221-231. https://doi.org/ 10.1016/j.jdeveco.2008.02.005

Noy I, Nualsri A (2007) What do exogenous shocks tell us about growth theories? In Working papers. Working papers no. 200728. University of Hawaii at Manoa, Department of Economics. https:// ideas.repec.org/p/hai/wpaper/200728.html

Noy I, Vu TB (2010) The economics of natural disasters in a developing country: the case of Vietnam. J Asian Econ 21(4):345-354. https://doi.org/10.1016/j.asieco.2010.03.002

Rahaman MM (2011) Access to financing and firm growth. J Bank Finance 35(3):709-723. https://doi. org/10.1016/j.jbankfin.2010.09.005

Raschky PA (2008) Institutions and the losses from natural disasters. Nat Hazard 8(4):627-634. https:// doi.org/10.5194/nhess-8-627-2008

Rodriguez-Oreggia E, Fuente ADL, Torre RDL, Moreno HA (2013) Natural disasters, human development and poverty at the municipal level in Mexico. J Dev Stud 49(3):442-455. https://doi.org/10. 1080/00220388.2012.700398

Romer PM (1986) Increasing returns and long-run growth. J Polit Econ 94(5):1002-1037

Romer PM (1990) Endogenous technological change. J Polit Econ 98(5):S71-102

Roodman D (2009a) A note on the theme of too many instruments. Oxf Bull Econ Stat 71(1):135-158. https://doi.org/10.1111/j.1468-0084.2008.00542.x

Roodman D (2009b) How to do Xtabond2: an introduction to difference and system GMM in stata. Stand Genomic Sci 9(1):86-136. https://doi.org/10.1177/1536867X0900900106

Rosselló J, Becken S, Santana-Gallego M (2020) The effects of natural disasters on international tourism: a global analysis. Tour Manag 79:104080. https://doi.org/10.1016/j.tourman.2020.104080

Runyan RC (2006) Small business in the face of crisis: identifying barriers to recovery from a natural disaster1. J Conting Crisis Manag 14(1):12-26. https://doi.org/10.1111/j.1468-5973.2006.00477.x

Schumpeter JA (1934) The theory of economic development: an inquiry into profits, capital, credit, interest, and the business cycle (SSRN scholarly paper ID 1496199). Social Science Research Network. https://papers.ssrn.com/abstract=1496199

Sivakumar MVK (2005) Impacts of natural disasters in agriculture, rangeland and forestry: an overview. In: Sivakumar MVK, Motha RP, Das HP (eds) Natural disasters and extreme events in agriculture. Springer, Berlin. https://doi.org/10.1007/3-540-28307-2_1

Skidmore M, Toya H (2002) Do natural disasters promote long-run growth? Econ Inq 40(4):664-687. https://doi.org/10.1093/ei/40.4.664

Strobl E (2011) The economic growth impact of hurricanes: evidence from US coastal counties. Rev Econ Stat 93(2):575-589

Tanaka A (2015) The impacts of natural disasters on plants' growth: evidence from the Great HanshinAwaji (Kobe) earthquake. Reg Sci Urban Econ 50:31-41. https://doi.org/10.1016/j.regsciurbeco. 2014.11.002

Tierney KJ (2007) Businesses and disasters: vulnerability, impacts, and recovery. In: Rodríguez H, Quarantelli EL, Dynes RR (eds) Handbook of disaster research. Springer, Berlin, pp 275-296. https://doi. org/10.1007/978-0-387-32353-4_16

Todo Y, Nakajima K, Matous P (2015) How do supply chain networks affect the resilience of firms to natural disasters? Evidence from the Great East Japan earthquake. J Reg Sci 55(2):209-229. https://doi.org/10. 1111/jors.12119

Tol RSJ (2018) The economic impacts of climate change. Rev Environ Econ Policy 12(1):4-25. https://doi. org/10.1093/reep/rex027

Toya H, Skidmore M (2007) Economic development and the impacts of natural disasters. Econ Lett 94(1):2025. https://doi.org/10.1016/j.econlet.2006.06.020

Uchida H, Miyakawa D, Hosono K, Ono A, Uchino T, Uesugi I (2014) Natural disaster and natural selection (HIT-REFINED working paper series no. 10). Institute of Economic Research, Hitotsubashi University. https://ideas.repec.org/p/hit/remfce/10.html 
Webb GR, Tierney KJ, Dahlhamer JM (2002) Predicting long-term business recovery from disaster: a comparison of the Loma Prieta earthquake and Hurricane Andrew. Glob Environ Change Part B Environ Hazards 4(2):45-58. https://doi.org/10.3763/ehaz.2002.0405

Weiss C (1998) Size, growth, and survival in the Upper Austrian Farm Sector. Small Bus Econ 10(4):305-312

World Bank (2010) Weathering the storm: options for disaster risk financing in Vietnam-Viet Nam. The World Bank report no. 70394. The World Bank. https://reliefweb.int/report/viet-nam/weathering-stormoptions-disaster-risk-financing-vietnam

World Bank (2014) Turn down the heat: confronting the new climate normal. The World Bank. https://openk nowledge.worldbank.org/handle/10986/20595

Ziliak J (1997) Efficient estimation with panel data when instruments are predetermined: an empirical comparison of moment-condition estimators. J Bus Econ Stat 15(4):419-431. https://doi.org/10.2307/13924 88

Zhou H, de Wit G (2009) Determinants and dimensions of firm growth (SCALES EIM research reports no. H200903). https://doi.org/10.2139/ssrn.1443897

Publisher's Note Springer Nature remains neutral with regard to jurisdictional claims in published maps and institutional affiliations. 